\title{
Leaders and followers: Perspectives on the Nordic model and the economics of innovation ${ }^{\text {斻 }}$
}

\author{
Joseph E. Stiglitz * \\ Columbia University, 3022 Broadway, 212 Uris Hall, New York, NY 10027, United States
}

\section{A R T I C L E I N F O}

\section{Article history:}

Received 2 December 2013

Received in revised form 3 September 2014

Accepted 17 September 2014

Available online 13 October 2014

\section{Keywords:}

Technological change

Research and development

Leader-follower

Scandinavia

\begin{abstract}
A B S T R A C T
What kinds of social and economic systems are most conducive to innovation? We formulate a simple model in which countries can close the gap with the technological leader, but where the cost of doing so may be so high that the country chooses to remain laggards. Observed disparities in productivity may be the result of a recognition that the cost of closing the gap exceeds benefit and there may therefore exist an international equilibrium in which there are leaders and followers. Even if it is granted that the United States is the leader and Scandinavia are followers, there are theoretical grounds for arguing that the Nordic model may in fact be better for innovation, suggesting that if the US adopted some of the Nordic institutions, innovations would be higher, and societal welfare would be improved even more.
\end{abstract}

(c) 2014 Elsevier B.V. All rights reserved.

\section{Introduction}

There are marked differences in productivity across firms and countries. We look up to the "leaders," those who are at the technological frontier and who are pushing that frontier ever forward. The laggards are urged to emulate the leaders. And yet, it is not apparent that it is optimal for them to do so. The lagging countries benefit from the lower prices that result from competition among the leaders. And both lagging countries and firms can benefit from the learning that results from the investments in R \& D and innovation of the leading firms, with far lower expenditures.

Even if profits at firms or standards of living in countries that are persistent leaders were persistently higher than those of firms that were persistent followers, it would not mean that the followers should change their corporate or national strategies. For there is a cost to catchup-large investments in learning-and these costs may well exceed the differences in profits.

\footnotetext{
is This paper is part of a broader work on innovation, undertaken with my colleague Bruce Greenwald, and of a more long standing research agenda undertaken with Partha Dasgupta and Giovanni Dosi. This paper in particular builds off of Greenwald and Stiglitz (2006, 2014). My debt to each is gratefully acknowledged. I am greatly indebted to Karle Moene, Brett Gordon, Martin Guzman, and two referees for their helpful suggestions. I also wish to acknowledge financial support from the Institute for New Economic Thinking (INET) (INO12-00039), and research assistance from Laurence Wilse-Samson, Feiran Zhang, Sandesh Dhungana, Eamon Kircher-Allen, and Quitze Valenzuela-Stookey.

* Tel.: +12128541481.

E-mail address: Jes322@columbia.edu.
}

This paper asks three central questions:

(a) What kinds of policies and institutional arrangements-what kind of economic systems-are most conducive to being an innovation leader-not just obtaining patents, but designing an innovation system that generates large and persistent increases in standards of living? Is it cut-throat competition? Or is the more gentle Nordic model, in which government takes on a larger role and in which a broad array of policies provides social protection and results in less inequality, more conducive to innovation?

(b) Should we expect that the policies of the follower differ from those of the leader, and if so, in what ways? Can we explain the successes of the Nordic model as a result of its policies being well adapted for the leader, or for the follower?

(c) Can there be an equilibrium in which some countries persistently remain leaders, and others followers? If so, can we say anything about the nature of the equilibrium and the kinds of policies pursued by each in that equilibrium?

Acemoglu et al. (2012) have recently put forward the hypothesis that the Nordic welfare model may be all well and good for the follower, but the American style of cutthroat capitalism, with its high level of inequality and strong incentives, is better suited for the countries at the frontier. While contentions of such a broad sweep are hard to evaluate with any precision, similar sentiments have played a central role in policy debates and therefore it is important to assess them, marshaling whatever theoretical, empirical, and historical arguments can be brought to bear on the issue. We thus begin with a general theoretical analysis (in Section 2) of why (i) unfettered markets are not likely to engage either 
in the optimal level or direction of innovation; and (ii) why government policies-including those that have characterized the Nordic countriescan and should play an important role. We follow this with a broad historical discussion and a closer look at (a) whether it is as clear as, say, Acemoglu et al. suggest that the US is in fact the technological leader; and (b) if so, to what that should be attributed. Section 3 provides an historical perspective on the U.S. experience.

Section 4 turns to the formulation of a leader/follower model in which there is a steady state with constant growth characterized by persistent differences in standards of living, without any convergence.

This analysis turns on its head a central contention of neoclassical growth theory since the work of Solow (1956), arguing that countries with different initial conditions should converge. In fact, the evidence on convergence has been disappointing. ${ }^{1}$ Our theory explains this absence of convergence.

In the leader-follower equilibrium, it is optimal for laggard countries to remain laggards, and never catch up. They sufficiently benefit from the dissemination of knowledge from the leader that it doesn't make sense for them to make the "Big Push" to join the club of leaders. But, except in some limiting cases, the followers are not fully passive-they pursue policies designed to close the gap between themselves and the leader, but even as they do so, the leader pursues policies that open the gap further. Not surprisingly, even though both leaders and followers pursue "innovation" policies, the policies that are optimal for each can be markedly different from those of the leader. We end the section with a discussion of several examples of such differences, but observe that the Nordic model may (with suitable adaptations) be desirable not only for leaders, but also followers.

We should emphasize at the onset that while we talk about leaders and followers, our characterization is too stark. Knowledge is multidimensional. Some firm/country could be on the knowledge frontier along some dimension, but well within the frontier on another. That is certainly true among countries that claim to be "at" or "near" the frontier, implying that they have a considerable amount to learn from each other.

\section{Market failures and innovation theory and policy}

\subsection{Market failures and innovation}

The fundamental theorems of economics argued for the (Pareto) efficiency of a competitive market economy. But the Arrow-Debreu model had nothing to say about innovation-the state of technology was assumed given. Schumpter (1943) had argued that contrary to the finding of standard welfare economics, monopolies (or more accurately, a sequence of monopolies, where firms competed to be the monopolist) were desirable, because they maximized the pace of innovation. A host of studies have shown that Schumpeter's conclusions were wrong, ${ }^{2}$ and

\footnotetext{
1 The empirical literature on convergence is complex (See DeLong, 1988; Durlauf and Quah, 1999; Dowrick and Nguyen, 1989; Barro and Sala-i-Martin, 1991; Mankiw et al., 1992; Im and Rosenblatt, 2013). This literature focuses on countries with the same production functions, assuming that knowledge flows freely across boundaries. It is precisely this question upon which Section 4 of this paper focuses.

2 Schumpeter claimed, moreover, that monopolies would be only temporary, and that competition to be the monopolist spurred innovation. Dasgupta and Stiglitz (1980a) showed that monopolies have the ability and incentives to persist, and Fudenberg et al. (1983), Dasgupta and Stiglitz (1988), and Stiglitz (1987a) show that incumbents can deter entry with only limited investments in innovation. Still, Schumpeter was partially correct: in a wide variety of circumstances, more competitive markets may be less innovative. Greenwald and Stiglitz (2014) develop several reasons for this: (a) while overall production for a monopolist is smaller, the production of each firm is larger, and incentives to innovate, e.g. for cost reducing innovation, are related to the scale of production of the firm. (b) The expected returns to investments in innovation depend on the chances of success, and that may be decreased if there is more competition in the innovation market (simply because there are more competitors.) But there are forces also going the other way: with imperfectly correlated research strategies among different firms, the more firms engaged in innovation, the higher the probability of success. And monopolies may suffer from "agency" problems (Hart, 1983): competition can be a spur to effort, e.g. as in a contest (Nalebuff and Stiglitz, 1983).
}

that the endogenous market structure and the associated levels and patterns of innovation arrived at by the market (which may be a monopoly or an oligopoly) can be improved upon by government intervention.

It should come as no surprise that markets are not efficient, since, with or without patents, ${ }^{3}$ social and private returns to innovation are markedly different, partly because of the difficulties of appropriating all the returns to innovation-knowledge spillovers are pervasive; partly because much of the returns that are appropriated are rents that otherwise would have accrued to other firms. Imperfections of risk and capital markets and of competition are other market failures that are inherently associated with innovation; firms have incentives to innovate in ways that enhance and extend their market power. ${ }^{4}$

Most fundamentally, knowledge can be viewed as a public good, and the private provision of a public good is essentially never optimal. While intellectual property may enhance the appropriation of returns, in doing so, it introduces a static inefficiency, in the restricted use of knowledge.

The myriad of ways by which private and social returns to innovation (with or without patents) differ lead to systemic inefficiencies, both in the level and direction of innovation. ${ }^{5}$ In the most innovative economies, governmental policies mitigate the consequences of these market failures.

\subsection{Translating innovation into higher living standards}

While it is often taken for granted that innovation makes society as a whole better off, this may not be the case. Some innovations may decrease the demand for some factors (unskilled labor-saving innovations ${ }^{6}$ ), even as they increase the productivity of others. The result is that some groups may be better off, others worse off. Innovation is not, in general, Pareto improving; and if those made worse off are poor individuals, social welfare is worsened, if we evaluate the change with an inequality averse social welfare function. Typically, the winners could compensate the losers, but in most societies, they don't. As a result most citizens can be worse off (cf. the US).

Indeed, recent research has shown how in the presence of imperfect and costly labor mobility, all (or almost all) individuals can be worse off. If, for instance, there is labor saving innovation in some sector at a fast enough pace (outpacing the growth of demand), employment and wages in that sector will fall. With imperfect mobility, workers in the innovative sector may be trapped. But as their incomes decline, they decrease their demand for goods from other sectors. The economy may enter into a sustained slump. ${ }^{7}$

There are other reasons that most individuals in society can be worse off in the presence of a faster pace of innovation: in the absence of adequate systems of social protection and redistribution, risk-averse individuals, uncertain of the effect of the change on their own well-being, will see a lowering of their ex ante expected utilities.

\subsection{National innovation systems}

Recent research comparing different economic systems has looked at markets as just one of many possible institutional arrangements by which resources get allocated, decisions get made, and risks get shared. (See, e.g. Hall and Soskice, 2001, and Esping-Andersen, 1990).

\footnotetext{
${ }^{3}$ Greenwald and Stiglitz (2014) provide a more comprehensive discussion of market failures and the ways in which social and private returns differ. For instance, the social return to faster innovation is the increased present discounted value of benefits from having the innovation arrive earlier than it otherwise would, markedly different from the private returns: the first to file the patent gets the entire innovation rents.

${ }^{4}$ There are numerous examples of each of these phenomena: patents aimed at enhancing hold-ups, research on me-too drugs, innovation directed at "evergreening."

5 See, e.g. Arrow (1962a); Stiglitz (1987b), Greenwald and Stiglitz (2014), and Dosi and Stiglitz (2014).

${ }^{6}$ See, e.g. Hicks (1932).

7 Delli Gatti et al (2012a,b) construct a model demonstrating this, arguing that it provides an interpretation both of what happened during the Great Depression and what has been happening in the Great Recession.
} 
This is especially relevant when it comes to innovation, where there has been a focus on national innovation systems ${ }^{8}$. The analysis of national innovation systems calls attention to the multiple inputs into the innovation process (skilled researchers, finance, the pool of ideas upon which researchers can draw) and multiple steps in the innovation process-from basic research, which underlies many of the most important advances, to applied research, from "big" innovations to the smaller refinements, which cumulatively may be far more significant. ${ }^{9}$ The pace of these follow-on innovations can be adversely affected by patents-the most important input into follow-on research is prior knowledge, and to the extent that the patent system makes access to this prior knowledge more difficult, the pace of follow-on innovation may be slowed. ${ }^{10}$

The single-minded focus on one part of the innovation process and one set of determinants (material incentives) may give misleading views on the overall determinants of the pace of innovation-and provide misguided policy advice.

For instance, David (2004a, 2004b) and Dasgupta and David (1994), building on a long tradition of work in the sociology of science (Merton, 1973), have argued that peer recognition is more important than pecuniary incentives. Societal attitudes-the acceptance of science, the questioning of authority, the embracement of change-are also pivotal. ${ }^{11}$

So too, more important than pecuniary incentives in determining the pace of innovation is the set of innovative opportunities, and the patent system, combined with cutthroat competition, encourages firms to try to take as much out of the available pool of knowledge and contribute as little to it as they can. The result is that policies (like stronger intellectual property rights) which, at any given size of the pool of knowledge, provide stronger pecuniary incentives may lead to a smaller set of "opportunities" available for others to draw upon, so much so that the pace of innovation will, under plausible conditions, actually be reduced (Stiglitz, 2014a).

Indeed, there is a large literature arguing that strong ${ }^{12}$ patent systems undermine innovation, even beyond the important adverse effects noted earlier in reducing the size of the pool of knowledge from which others can draw and by increasing the cost of access to knowledge, partly by diverting scarce innovative resources to circumventing and extending patents and enhancing the monopoly power that is derived from patents, and partly because of the patent thicket and hold-ups to which it is increasingly giving rise. ${ }^{13}$

\footnotetext{
8 See Freeman (1995), Lundvall (1992), Nelson (1993), Patel and Pavitt (1994), and Dosi et al. (1988)

${ }^{9}$ See, e.g. Nordhaus (1969).

10 There is an extensive literature detailing the adverse effects of the patent system on follow-on innovation. A recent dramatic example is provided by the patent on the BRAC genes (which play a critical role in determining the likelihood that a woman gets breast cancer.) Before the US Supreme Court ruled against the patenting of genes, Myriad, the patent holder, suppressed the development of better tests for identifying the presence of the gene.

11 These attitudes themselves are, at least to some extent, endogenous, and are affected by the economic and political system.

12 There are many dimensions to a patent system, so that it is not always possible to identify when one patent system is stronger than another. Some of the adverse effects of "strong" patent systems derive from particular features, e.g. the absence of well-defined provisions for "opposition," resulting in over-patenting (see Henry and Stiglitz, 2010), the granting of excessively broad patents, or patents lacking in sufficient novelty. Some of the adverse effects associated with, say, the US patent system could be ameliorated by patent reform. Others could not.

${ }_{13}$ There is a large body of research on each of these topics, and several overall assessments of the contribution of the patent system to innovation. See, e.g. Boldrin and Levine (2013); Greenwald and Stiglitz (2013, 2014); Heller (1998) Heller and Eisenberg (1998); Huang and Murray (2008); Moser (2013), Williams (2010,2013). On the subject of patent thickets and hold-ups, see, e.g. Budish et al., 2013; Shapiro (2001, 2010). It appears that the patent thicket is a particular problem in certain sectors, e.g. software and nanotechnology. See European Commission (2008), Clarkson and DeKorte, 2006.

Historically, the adverse effects of the patent system in the development of the automobile and the airplane have been often noted. Most recently, Goldstone (2014) notes that the attempt by the Wright brothers to inhibit follow on innovation had a disastrous effect on the development of the American airplane industry, to the point where with the onset of World War I, no American plane was good enough to go into combat. The industry only developed once the government insisted on cross-licensing.
}

There are still other reasons that the patent system may not lead to a higher standard of living or a faster pace of its increase. It undermines the "open" architecture characteristic of the best innovation systems, which has traditionally been viewed as one of the virtues of research universities. Openness affects not only the pace at which the frontier is moved out, but the pace by which frontier ideas disseminate within a country. Even in the best performing economies, there are large gaps between best and average practices. ${ }^{14}$ A reduction in that gap can lead to substantial increases in productivity and standards of living. Even if the patent system, for instance, resulted in the frontier moving out faster, it might actually impede the closing of the knowledge gap.

Strong financial incentives especially when combined with the patent system can actually be counterproductive for other reasons: a focus on strong financial incentives helps create value systems that put less emphasis on the pursuit of knowledge-so essential for basic research which is the foundation upon which all innovation rests-than on the conversion of existing knowledge into marketable products. But unless the wellspring from which applied technology draws is replenished by advances in basic science, eventually the pace of applied innovation itself will have to slow. Moreover, in science, because peer recognition plays a far more important role than financial rewards, a system that emphasizes material rewards effectively downgrades the relative importance of the incentive structure that is at the core of science.

Furthermore, a hallmark of American-style financial capitalism is its short-termism, its focus on quarterly returns, which is antithetical to the undertaking of long-term major innovation.

Moreover, the flow of resources into any activity depends on relative rewards. The financialization of the American economy has resulted in disproportionately large rewards to those in the financial sector, discouraging more talented individuals from engaging in socially productive research.

Behavior is affected not only by how much one wins when one succeeds, but also the consequences of failure. Research is very risky, and the amount of risk-taking that is undertaken within any society depends on how risks are mitigated. We argue below that it is not selfevident that American style capitalism provides the best system of risk mitigation. National innovation systems involve, of course, more than the design of financial incentives. ${ }^{15}$ A country's national innovation system determines the flow of resources (inputs) into innovation in other ways. The other vital input into research, besides access to prior knowledge, is trained personnel. This requires an educational system that taps into the most talented individuals, regardless of the education and income of their parents. The Scandinavian countries have achieved the highest level of opportunity, the US, the lowest level among the advanced countries. ${ }^{16}$

Earlier, we noted that there were many stages to the innovation process. All innovation rests on the foundation of basic research, which is overwhelmingly financed by government. But government even plays an important role in financing applied research. ${ }^{17}$ Recent research has highlighted the role of the entrepreneurial state in promoting innovation. Mazzucato (2013) shows that even the United States has, almost from the start, been a developmental state, in which government promotes new industries and sectors (such as telecommunications, through investments in the first telegraph line, and creating the Internet), and in which government plays a leading role in increasing productivity in established sectors, like agriculture (both through research and extension services). ${ }^{18}$ Governments have actually played

\footnotetext{
14 See Baily et al., 1992; Greenwald and Stiglitz (2014) and the references cited there.

15 For a further critique of the role of financial incentives, see Dosi et al., 2006.

16 See Stiglitz, 2012a and the references cited there.

17 In the US, the federal government funds around 30\% of R \& D and more than half of basic research (National Science Foundation, 2014. Figures are for 2011, which was the most recent available data at the time of writing. http://www.nsf.gov/statistics/seind14/index. cfm/chapter-4/c4h.htm).

18 Other recent studies of innovation (e.g. Janeway (2012)) have echoed earlier studies (List 1841) on the importance of the state.
} 
key roles in financial sector innovation, in the kinds of innovation that actually led to greater societal well-being-helping create deep mortgage markets and banks oriented to the provision of long-term credit.

The reasons that the government has played this pivotal role can be closely linked to the "market failures" described earlier in this section. Diffuse externalities help explain government support of agricultural research. Capital constraints seem to have played a dominant role, especially in the context of inadequate systems of risk sharing and in situations where the scale of the required investment is very large. ${ }^{19}$

In short, creating a learning/innovation economy and society entails far more than just establishing strong monetary incentives; and such incentives may in fact have an ambiguous effect on the pace of innovation that increases living standards. ${ }^{20}$

\subsection{The Nordic model, cutthroat competition, market failures, and innovation}

In this section, we address the critical question of "comparative innovation systems": Why might we expect societies that follow the Nordic model to be highly innovative? By the same token, we ask, if the United States is the innovation leader, to which of the policies and institutional structures do we attribute its success? Is it, as Acemoglu et al. suggest, because of its cutthroat competition? If the Nordic model is not good for innovation, the question is, what aspects of that model are most problematic? ${ }^{21}$

Among the common attributes of the Scandinavian model are low inequality, ${ }^{22}$ partly a result of wage compression, partly the result of tax and transfer policies; strong systems of social protection; strong policies of gender equity and child protection; high levels of openness; proactive industrial and labor policies, including heavy government investments, efficiently executed, in education, technology, and infrastructure; strong and open democracies, with strong support for a competitive and critical press and a long tradition of right-to-know laws. Presumably, critics of the Nordic model are not complaining about the openness and transparency of government or of its efficiency,

\footnotetext{
19 Schumpter (1943) emphasized the importance of capital constraints, e.g. because research (unlike investments in real estate) could not be collateralized. While venture capital funds have been an important American innovation, providing funds to new research enterprises, their scope is still very limited, both in scale and across sectors.

20 We could formalize the insights provided in this section by hypothesizing that the pace of innovation (say measured by the rate of labor augmenting technological progress in productive enterprises) I is a function of (a) the level of private investment in innovation, i; (b) the supply of critical inputs, like trained personnel, $\mathrm{E}$ (or the cost of such personnel, itself a function of $\mathrm{E}$ ); (c) the set of opportunities, $\mathrm{P}$; and (d) the fraction of the private investment that goes into socially productive investments, as opposed to me-too-research, research directed at increasing the ability of private firms to exploit market power or to take advantage of others (e.g. by increasing the addictiveness of cigarettes), $\beta$; and (e) the productivity of these investments, e.g. either in terms of how productive inputs translate into innovations (e.g. as a result of a focus on long term versus short term returns), or in terms of how quickly these innovations disseminate through the economy, leading to increased productivity, $\zeta$. Each of these variables, in turn, are a function of the design of the economic system, e.g. the patent system, the system of financial rewards (including the progressivity of the tax system), the systems of social and intellectual property rights protection, the educational system, competition policy, bankruptcy laws, etc. The nature of financial awards is just one factor, and not the most important factor, in determining the pace of innovation; indeed, the total derivative of the pace of innovation with respect to an increase in financial rewards (the degree of cutthroat-ness of the economy) may well be negative. Stiglitz (2014a).

21 Any normative discussion of comparative institutional analysis has to address the issue of how one is to assess performance. The analysis of the previous subsection has explained why we should not focus on an intermediate measure, like expenditures on R \& $\mathrm{D}$, since those expenditures may not be directed at improving societal performance, but rather at enhancing market power. Commonly, the focus is put on GDP, but a wide body of research, growing out of the work of the international Commission on the Measurement of Economic Performance and Social Progress (Stiglitz et al., 2010) has emphasized the inadequacy of that metric (especially if one evaluates welfare using an inequality-averse social welfare function).

22 Fochesato and Bowles (2014) argue that what is distinctive of the Nordic countries is not equality in wealth but equality in living standards and in mobility. Blundell et al. (2014) describe the role that Norway's progressive tax-transfer system plays in attenuating the magnitude and persistence of income shocks.
}

but rather the diminution of incentives, particularly associated with its egalitarianism.

Here, I want to argue that there are theoretical grounds for arguing that the Nordic model may in fact be better for innovation than the "American" model-suggesting that if the US adopted at least some of the institutional arrangements that are associated with the Nordic model, innovation would be higher-and societal welfare would be improved even more.

\subsubsection{The meaning of cutthroat competition and its impact on innovation}

Acemoglu et al. argue for the American model on the basis of the stronger incentives that its cutthroat competition provides, the increased financial rewards, and its strong intellectual property protection. ${ }^{23}$ Assessing the relationship between some notion of competition and the level of innovation directed at increasing standards of living is, at best, difficult. More competition in research (to be the next dominant firm in a Schumpeterian world with sequential monopolies) may reduce the marginal return to research and therefore the level of investment of each firm, more than offsetting the benefits of having additional researchers. More competition in the product market typically reduces the scale of production of each firm, and therefore attenuates incentives for cost reduction.

The analysis of the previous subsections, establishing that unfettered markets lead to Pareto inefficient outcomes, has an immediate implication: unrestrained markets do not result in the optimal level of socially productive innovation. To be sure, they may result in more innovation of an unproductive form (enhancing, for instance, market power or the ability of firms to exploit others). Cutthroat competition can be associated with actions (such as that of Microsoft) discouraging the entry of rivals, and thus impede innovation. Competition policy restricting such anti-competitive practices ("cutthroat competition") will have a beneficial effect on innovation. ${ }^{24}$

So too, we have explained how stronger intellectual property rights, even if they lead to more innovation given a set of technological opportunities, under plausible conditions lead to less innovation because of adverse effects on the set of technological opportunities available for development.

There are still other interpretations of what might be meant by cutthroat competition: a culture that glorifies litigation at the expense of cooperation. But this litigation exerts a large toll on the innovative process, with some suggesting that as much is being spent on litigation as on research itself (Dosi and Stiglitz, 2014; Cimoli et al., 2014b) and the constant threat of suit as a result of the patent thicket dampening innovation. ${ }^{25}$

If cutthroat competition is set in contradistinction to cooperation, there is another reason that its effects can be adverse: Cooperation is

\footnotetext{
${ }^{23}$ Interestingly, in many manufacturing sectors, US R\&D outlays by the private sector as a percentage of sales is lower than in other countries. In office, accounting, and computing machinery, in 2008 it was only $13.6 \%$, compared to Sweden's $13.9 \%$; in electric machinery, it was $2.5 \%$, compared to Sweden's 3.2\%, and Japan's 8.0\% (France was 3.5\% in 2006); in motor vehicles it is $3.2 \%$, as compared to Japan's $4.4 \%$, and Germany's $5.0 \%$ (France was $4.4 \%$ in 2006). (OECD Structural Analysis (STAN) database.) (One has to be careful about the use of reported R\&D data for certain sectors, such as pharmaceuticals, because marketing expenditures are intertwined with R\&D expenditures, contributing to the high levels of reported research in that sector.)

${ }^{24}$ There is a large literature showing the adverse effects of such cutthroat competition. It is, for instance, often associated with attempts to raise rivals' costs (Salop and Scheffman, 1983), socially destructive activities that put one at an advantage over competitors. Moreover, dominant firms may engage in ruthless practices to foreclose opportunities of rivals-the actions taken by Microsoft against its competitors Netscape and RealNetworks, firms that were the real innovators, provide telling examples. While some of its actions were eventually found to violate anti-trust laws, its strategy worked-the rivals never recovered-with a chilling effect on other potential innovators. There is a large literature discussing the relationship between the level of competition (as measured, for instance, by the number of firms or by some other measure of firm concentration) and the level of innovation. (Scherer, 1967; Aghion et. al. 2005; Vives, 2008; Gilbert, 2006). But as Dasgupta and Stiglitz (1980b) and Goettler and Gordon $(2011,2014)$, in general, both the level of competition and the pace of innovation are simultaneously determined endogenous variables.

${ }^{25}$ The adverse effect of this litigation on the development of key innovations, such as the airplane, have been extensively discussed (see, e.g. Goldstone (2014) and Stiglitz (2006a).
} 
particularly important in the context of complex products requiring large numbers of innovative inputs. ${ }^{26}$

Finally, "cutthroat competition" could mean a social system in which there are weaker social protections. We will explain later why stronger social protection may actually have a positive effect on innovative activity.

Acemoglu et al. have constructed a model showing that for one interpretation of cutthroat competition more competition could lead to more innovation: but the results follow directly from the assumptions; they are hard-wired into the model. It should be obvious that one can write down models in which more cutthroat competition or less progressive taxation or stronger intellectual property rights lead to a faster pace of innovation. But that is not the question, for it is equally possible to write down models with just the opposite results, where strong intellectual property or more intense competition leads to lower levels of innovation, and elsewhere we have done that. ${ }^{27}$ Contrary to Acemoglu et al., it is simply not the case that institutional arrangements that lead to more cutthroat competition will necessarily be associated with higher levels of investment in innovation, let alone higher standards of living.

Our earlier discussion explained that a society's innovation system is far more complex. If the US is the most innovative country, there are many other reasons other than cutthroat competition why this might be so. The success of the US may have more to do with the large role played by the government than to the entrepreneurial role of the private sector (Mazzucato, 2013). Even when we turn to private sector innovation, we find a picture quite different from that painted by Acemoglu et al. Probably the most innovative American firm during the twentieth century was a regulated monopoly, largely shielded from competition, with its research budget funded by, in effect, a tax on telephone service. ${ }^{28}$ There are several reasons why that was so: some of these are related to the fact that because a monopolist has a larger output (than say a duopolist, where though total output is higher, the amount produced by each firm is smaller) it has more incentive to bring down costs. Moreover, shielded from cutthroat competition, it could focus on the long run, including the benefits which it might receive in the long run from investments in basic research.

Elsewhere, we have provided a more general analysis of the relationship between innovation and competition (however assessed), showing that it depends on a variety of characteristics, e.g. of the stochastic process of innovation, the substitutability among goods, the nature of the market barriers, etc. This suggests that the American model may be good for innovation in certain areas, adverse in others.

\subsubsection{Broad perspectives on institutional design}

There are several key aspects of the Nordic model that may be particularly conducive to innovation. Earlier, we noted the importance of the (inherent) absence of a full set of risk and capital markets, both for the efficiency of the economy in general and for innovation in particular. Research is risky, and better systems of social protection can thus be more conducive to individuals undertaking research. Even high taxes can be conducive to risk taking: the government can be seen as a silent partner, sharing in the gains as well as losses, with the result that there will be more risk taking. ${ }^{29,30}$

\footnotetext{
${ }^{26}$ When cooperation is achieved, it is often achieved in a way which make it more difficult for new firms to enter the market. The established firms create a patent pool, but intellectual property acts as a strong and effective barrier to entry.

27 Greenwald and Stiglitz (2014) and Stiglitz (2014a,b,c).

28 See Gertner, 2012

29 This is the essential insight of Domar and Musgrave (1944) and Stiglitz (1969). The details of the tax system affect the extent of risk sharing, and thus the extent to which innovation is encouraged.

30 Earlier, we referred to the important role that social attitudes and mores can play: the Enlightenment was a change in mindset, and that change in mindset was far more important than any change in property rights or incentive structures. So too here: attitudes towards failure can affect individual's willingness to undertake risks. The determinants of these social attitudes would take us beyond the scope of this paper; but there is a growing body of research emphasizing the role that government policies can play. See World Bank 2015
}

A major input into research is high quality research personnel. Without government intervention, because of imperfections in risk and capital markets, ${ }^{31}$ there will be insufficient investments in education. In the US, with heavier reliance on private financing of higher education, with its adverse bankruptcy laws (in which student loans are essentially impossible to discharge), with the virtual absence of income contingent loans, investments in education-especially in areas where returns are risky and limited, such as in science-will be more limited. And access to quality education by those whose parents have limited income will be greatly circumscribed.

Worse still, given the high cost of higher education and the skewed material rewards system, it is not a surprise that a disproportionate share of the most talented individuals have, in recent years, gone into finance; and while that may have resulted in a higher level of innovation in the financial sector, it has not resulted in a higher overall pace of innovation in the relevant sense-an increase in standards of living, or the pace by which standards of living increase. Indeed, much of the innovation was directed at figuring out better ways of manipulating the market, exploiting more those who were financially unsophisticated, enhancing the ability to leverage market power, and circumventing regulations that attempted to stabilize financial markets and reduce the risk of large adverse externalities. ${ }^{32}$ While these innovations may have generated more rents for those in the financial sector, there is no evidence that they improved the overall performance of the economy.

Education is not the only critical factor that is complementary to private investments in innovation. Good investments in infrastructure can increase the returns to private investments (Field, 2011) in general, including investments in innovation.

The Nordic model, with heavier public investments in education, technology, and infrastructure, progressive taxation that reduces incentives for rent seeking, and better systems of social protection, increases the willingness and ability for innovative risk taking. For an excellent discussion arguing that that is in fact the case, see Barth et al., (2013), and Moene (2013). They go further, showing that in a vintage model of innovation, wage compression induces older vintages to be scrapped earlier, thus accelerating the process of creative destruction. ${ }^{33}$ Moreover, they show how government policies can ensure that society as a whole benefits from innovations, e.g. through the active labor market policies and Keynesian demand policies that are part of the "Nordic model." Further, the Nordic model can lead to faster dissemination of ideas throughout the economy (in ruthless competition, firms strive to keep whatever knowledge they acquire to themselves).

\subsubsection{Specific policies}

There are many more specific policies in the Nordic model that enhance innovation. Consider the narrower question: could innovation be encouraged by taxing financial and land speculation more and using the proceeds to invest more in education, especially for science and technology; or to pay scientists more, to attract more into these innovative activities? Standard arguments would suggest that higher taxes on land will not affect the land supply. And given the evident low (negative) marginal social returns to innovations in the financial

\footnotetext{
31 This is not the only reason that there may be underinvestment in education. Some individuals, particularly from underprivileged families, may not fully appreciate the returns to education; the assumption of fully rational expectations assumed in conventional models is clearly wrong. Most individuals rely on public provision of education at the elementary and secondary level, and there may be under provision of investments, especially in communities in which there are large numbers of poor individuals, especially in divided societies where rich individuals have access to private schools.

${ }^{32}$ For instance, the gains of the High Frequency Traders occur at the expense others, but this rent-seeking not only uses real resources makes markets less informative, with adverse effects on the efficiency of resource allocation. See Stiglitz (2014e) and Biais and Woolley (2011).

33 There is a long tradition among economic historians arguing for the innovation benefits of high wages and labor scarcity. See, e.g. Salter (1966), Habakkuk (1962), Sutch (2010), and Wright (1986). For a theoretical discussion, see Acemoglu (2010), Greenwald and Stiglitz (2014), and Stiglitz (2006b, 2014d).
} 
sector, the reallocation of resources in ways that are associated with the Nordic model would presumably be "real" innovation enhancing. Or consider the slightly broader question: could innovation be enhanced by taxing those at the top at higher rates, and using the proceeds in a similar way? It has been argued that because much of the income is derived from rent seeking, ${ }^{34}$ an increase in taxes at the very top has little effect on growth (Piketty et al., 2011).

While Section 4 will show that the optimal policy of the leader and the follower will be different, this analysis suggests it is not necessarily the case that the leader has less of a "social model" than the follower.

The Nordic model consists of exactly the kind of policies that one would expect to see in a leader. While it may not be optimal for all countries to follow the same model, those countries that aspire to be on the frontier should at least consider emulating some aspects of the model that has worked so well in the Nordic countries, not only in maintaining a high rate of growth in productivity, but high levels and rates of growth in standards of living.

\subsection{Political and economic equilibria}

The discussion so far has explored the consequences of alternative economic policies; but as is now widely recognized, public policies are enacted through political processes, which themselves are affected by the economy, including by the extent of inequality. We have to view the economic and political equilibrium as being jointly determined. It is easy to show that there can be multiple equilibria. ${ }^{35}$

In particular, there can be an equilibrium with a high level of inequality supporting low levels of public investments (including in education and technology), low levels of tax progressivity, and high levels of rent seeking, generating high levels of inequality; and another equilibrium with a low level of inequality with high levels of public investment, high levels of progressivity, a strong welfare state, and strong policies against rent seeking (the Nordic model). The representative individual is likely to be better-off in the latter-and so is the pace of innovation. ${ }^{36}$

There is no reason to believe that the US has adopted the policies that it has because they are designed to maximize innovation, let alone societal welfare, rather than because they are simply the outcome of political processes in which those with money have disproportionate influence, an outcome that one might expect given its high level of economic inequality. ${ }^{37}$

This analysis suggests that the US could increase the pace of innovation (and the level of economic welfare) by making some moves in the direction of the Nordic model. Not only would the institutional and policy reforms promote greater innovation directly, but by reducing inequality and the insecurity associated with innovation and openness, generate more support for innovative policies and ensure that those displaced by innovation are "recycled"-retrained so that they can be more productive members of the economy.

Many aspects of the Nordic model were explicitly designed with this political-economic equilibrium in mind. (See Barth et al, 2012). The Scandinavian countries are small. To be prosperous, they had to be open to the outside world. But openness imposes high costs on many individuals. So too for innovation. And in truly democratic societies, if a

\footnotetext{
34 See Stiglitz (2012a) and Piketty (2014) and the references cited there.

35 See, e.g. Hoff and Stiglitz, 2004.

36 There are multiple links between inequality and the economic-political equilibrium. More divided societies are less likely to make high return public investments; the rich seek a weaker state, worrying that it might use its powers to redistribute. See Stiglitz (2012a) and the references cited there. See also Benabou (1997) for a survey of studies on economic growth and inequality, and Ostry et al. (2014) for more recent evidence.

${ }^{37}$ I say this with some confidence, having watched closely and participated in decision making in the US, and especially relevant for this paper, decision making related to innovation, such as the design of intellectual property rights and the level and pattern of expenditures on research. Special interests often dominated; the question of what was good for the progress of science or the advancement of health was given short shrift. For a discussion of some aspects of this, see Stiglitz, 2006a.
}

majority of citizens are losers-even if a minority are large "gainers"it will be hard to sustain policies supporting innovation and openness.

To sustain innovation and openness, one either has to move away from democracy (e.g. by moving towards a system where money has more influence), so that the winners have a disproportionate role in determining outcomes, or one has to ensure that a majority of citizens are in fact better off-and that is the intention of the Nordic model.

\section{Historical perspectives and the U.S. experience within a historical context}

Even if the US is the technological leader, there are several possible explanations, which we cannot adequately assess within the confines of this limited paper. But an historical analysis is suggestive. The United States was not always the leader. In the nineteenth century, it borrowed voraciously from Europe. (See, e.g. Chang, 2001, 2002). Interestingly, even then, when it was a follower, it had a form of capitalism that was marked by high inequality-the extremes of the Gilded Age have only been reached in the Roaring 20s and in the first decades of this century. The innovator of the period, Germany, was the first country to introduce social security. The pattern clearly seems to be the opposite of that suggested by Acemoglu et al.

World War II marked a turning point in US technological leadershipa historical accident, partially at least a "gift" of that war, as large numbers of those on the forefront of science and technology fled to the US.

This leadership was then reinforced as a result of government actions, in response to the Cold War, that led to heavy investments in military research, which had large spillovers to the civilian sector (including, arguably, the development of the Internet.) The large technological leadership of American universities, reinforced by World War II and government Cold War investments in the decades following the War, attracted some of the most talented young people from around the world, many of whom stayed in the United States. But note that none of these schools are for-profit institutions. They are either not-for-profit or state institutions.

A closer look at many of the critical inventions and innovations that have transformed the economy shows that they were not the result of cutthroat competition. They were financed either by government or by a monopoly (Bell Labs). Innovations attributed to the latter include the transistor, the laser, the CCD, information theory, and the programming language UNIX. ${ }^{38}$

If America is the innovation leader, it is hard to ascribe its position solely, or even mainly, to cutthroat competition. There are, in fact, multiple institutional and cultural factors that influence the ability of a technological leader to maintain that leadership position. ${ }^{39}$

On the positive side, for instance, America's attitude towards bankruptcy-its acceptance of bankruptcy as part of the price to be paid for risk taking in an innovative context-and the development of the venture capital industry are two institutional characteristics that are highly conducive to innovation. ${ }^{40}$ But even in these areas of strength, there are questions: US bankruptcy law gives first claim to derivatives, and student loans can almost never be discharged, even in bankruptcy. This distorts the allocation of resources-towards finance and away from higher education, distortions that almost surely result in less real innovation than there would otherwise be.

\footnotetext{
38 In addition, there were many innovations that were of less commercial relevance, such as the development of radio astronomy. Many of these developments rested in turn on theoretical insights derived from research in other countries, supported by government or academic institutions. As we noted earlier, Bell labs was essentially funded by a dedicated research tax on all telephone services. See Gertner (2012).

39 For a more extensive discussion of these issues, see Greenwald and Stiglitz, 2014.

40 Though Mazzucato (2013) persuasively demonstrates the limited role of the VC industry in innovation. The venture capital industry is a very small part of the financial sector, and was adversely affected by the global financial crisis, brought on by the dominant part of that sector. Kaplan and Lerner (2010) find that historically venture capital investments in companies represent a remarkably constant $0.15 \%$ of the total value of the stock market.
} 
While the quality of its elite universities is clearly a favorable factor, the unevenness of the quality of its education-and the evident deficiencies in average performance (e.g. as measured in PISA scores ${ }^{41}$ ) work in the opposite direction. So too does the fact that such a large fraction of its innovative talent has been diverted to finance (and zero sum activities within finance) and other rent-seeking activities.

While large corporations may have access to the large amount of resources needed to undertake large, long-term research projects, the misalignment of interests between management and shareholders and more broad societal interests, widely recognized deficiencies in corporate governance (leading often to excessive short termism), and the bureaucratic processes that many large corporations have established as part of their control mechanism, may enervate innovation, especially of the kind that enhances standards of living.

\subsection{Is the US the leader?}

The central contention of this paper is that the Nordic model is not only good for the well-being of most citizens, but that it is also good for innovation.

But the discussion of the previous section begged the question: Is the US really more innovative? Establishing that would require showing that there was a disproportionate flow of innovations, appropriately weighted, from the putative leader, the US, to the Scandinavian countries, adjusting, of course, for differences in the size of the two countries.

It should be clear that assessing the level of innovativeness of an economy is no easy matter. Earlier, we explained that American higher levels of investment in innovation do not necessarily lead to an enhanced pace of increases of standard of living overall, and especially so for the typical household, especially given the marked discrepancies between social and private returns. Even assessing the importance of any particular innovation may be difficult. Moreover, in a world in which knowledge flows in all directions, assessing the origins of any idea is nearly impossible. For instance, many of America's recent advances in medicine build on work done in the United Kingdom by Watson and Crick leading to the discovery of DNA. America's development of the computer rested on fundamental work done by Alan Turing in the United Kingdom. Parsing out the source of the "real" innovations is difficult if not impossible.

The Swedish innovation of worker quality circles or the Japanese innovation of just-in-time production-neither of which were patentedmay have had more profound impacts on American productivity than that associated with multiple patents. To be sure, Scandinavia benefited from Intel's innovations in chips, but presumably the value of those patented innovations would be (largely) captured in the profits of the patenting company, and in the GDP of the originating country.

Interestingly, while many suggest that the US has been highly innovative, say in the last thirty-odd years, it doesn't seem to show in GDP statistics, where increases in GDP per capita, or even estimates of total factor productivity growth, seem to be far lower than in the decades after World War II. There are several possible explanations for this. Perhaps GDP does not really capture the improvements in living standards that computer-age innovation is engendering. This may be partly due to the fact that GDP does not provide a good measure of well-being (see Stiglitz, Sen, and Fitoussi, 2010), though there are reasons to believe that when full account is taken, for instance, of the increase in insecurity, economic performance is even more dismal than GDP statistics suggest.

\footnotetext{
41 The Programme for International Student Assessment, administered by the OECD, evaluates 15-year-old students' aptitude reading, mathematics, and science literacy. According to PISA, the US education performs at about the average level of OECD countries overall, but lags behind the OECD average in mathematics (Organisation for Economic Co-operation and Development, 2011). The low level of equality of opportunity implies those born to poor and poorly educated parents are less likely to live up to their potential. See Stiglitz, 2012a. These adverse outcomes can be thought of as a natural outcome of the American model of capitalism, which has led to high levels of economic inequality, especially given the manner in which these economic inequalities interact with political processes (as noted in the previous section), leading to low levels of public investments.
}
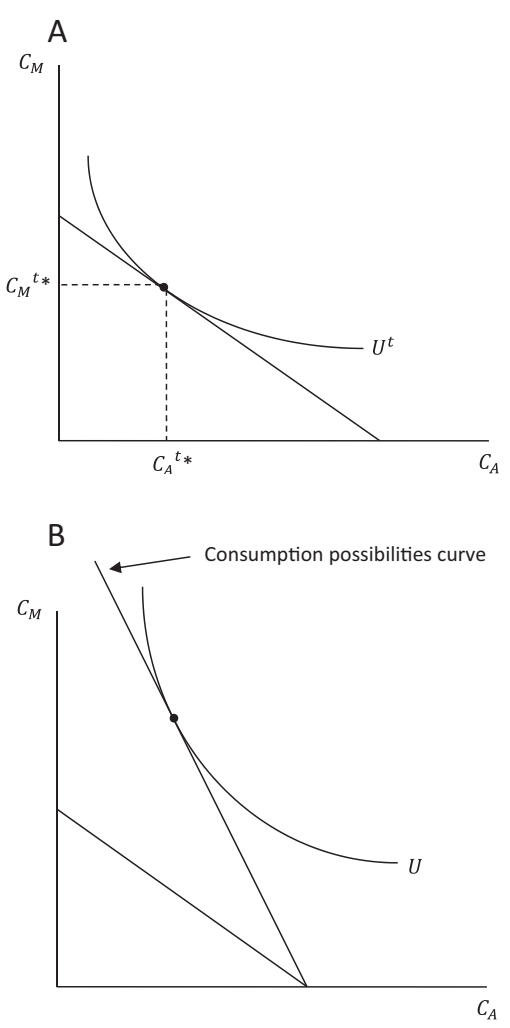

Fig. 1. A: The production possibilities curve is a straight line with a negative slope of $-c_{A} / c_{M}$. First-period equilibrium in the absence of trade occurs at the tangency between the production possibilities schedule and the indifference curve, at $C_{M}^{t^{*}}, C_{A}^{t *}$. B shows the country's "consumption possibilities curve," which because of trade is far better than its production possibilities curve.

Alternatively, it may be that as exciting as recent innovations seem, they are less significant than the enthusiasts believe. The United States may have made great strides in inventing better ways of targeting advertising, or designing financial products that are better at exploiting uninformed individuals. It takes innovativeness to design better ways to exploit and leverage market power, and this is likely to show up in higher profitability. But these "innovations" may not show up in GDP statistics.

\subsubsection{Macro-data}

Data on levels of GDP or its growth (partly for the reasons just alluded to) do not adequately answer even the question of which country is more advanced or more innovative. Resource-rich countries have high incomes, but those incomes have little to do with innovativeness. And the discovery of new resources and their exploitation or an increase in the price (or scarcity value) of its resources may lead to a high rate of growth-but this growth cannot be attributed to innovativeness. The US has benefited from an abundance of natural resources, and certainly at various times in its history, its growth has been enhanced by the discovery of new resources or an increased ability to exploit them (some of which may, of course, be related to innovativeness).

Norway's recent growth and its current income per capita exceed that of the US, ${ }^{42}$ but that is clearly related to the discovery of oil and gas. But Barth et al (2013) show that looking over the 80 year period from 1930 to 2010, Sweden and Norway have had a growth rate that exceeded that of the United States and other countries of Western Europe with less strong welfare systems.

42 At official exchange rates, in current US dollars, the United States GDP per capita was $\$ 49,965$ in 2012 , while that for Norway was $\$ 99,558$. At PPP (current international dollars), Norway's GDP per capita was still considerably greater than the US, at $\$ 65,640$ in $2012(2011,2010)$. The real GDP growth rate in US was 2.2\% in 2012, while this number in Norway was 3.1\%. Source: World Bank DataBank. 
Moreover, output per worker hour in several countries exceeded that in the US (Norway by $41 \%$, Ireland by $15 \%$, Luxembourg by $30 \%$, Belgium by .5\%), and in several (Germany, France, Netherlands Denmark) the differences were small. ${ }^{43,44}$

By most accounts, Sweden and Norway have a higher standard of living or welfare (e.g. reflected in say median income or UNDP's Human Development Index). ${ }^{45}$

\subsubsection{Patents ${ }^{46}$}

Acemoglu et al. try to establish the greater innovativeness of the US by looking at highly cited patents (registered in the US patent office) per million residents. Putting aside technical issues, such as differences in demographics and the presumed lower overall transaction cost associated with an American registering a patent in the United States versus a foreigner registering in the United States, there is a more fundamental issue-patents play markedly different roles in different sectors. In some sectors, like hi-tech and pharmaceuticals, they play a very important role, though in the former often more in a "defensive" way, to put oneself in a position to countersue when someone sues. In other sectors, like metallurgy, they play a very unimportant role.

By the same token, the number of citations is not necessarily a good index of importance. We referred earlier to two critical innovationsjust-in-time production and quality circles. These were not patented, and accordingly, there is no index of the number of citations. But there is little doubt of the profound effects. Or take another Swedish innovation: dental implants. Whether the original research spawned a large follow-on research, with many citations, is not the critical determinant of the impact that this innovation had on the quality of life of hundreds of millions of individuals. (Moreover, to repeat what we argued earlier: perhaps the most important American innovations of recent decades-the transistor, the laser, and the Internet-were the product either of government-funded research, or research funded by a dedicated tax to the telephone monopoly.)

And, the most important innovations, generating the most cited research, typically cannot be patented-from the Turing machine, to the discovery of DNA and electromagnetic fields. ${ }^{47}$

In short, it may be the case that the US is more innovative, in a relevant sense, than some of the Scandinavian countries, adjusted for size. But the case has yet to be made in a convincing manner. And if it is more innovative, in some sense, it is not the case that this higher level

\footnotetext{
43 According to OECD data for 2012. And taking into account some of the measurement problems noted by the Commission on the Measurement of Economic Performance and Social Progress, the US probably had an even smaller GDP per hour worked.

${ }^{44}$ The interpretation of such data are open, of course, to multiple interpretations. The numbers can depend on the degree of vertical integration (if there are some parts of the production process with higher value added per worker, a country specializing in those stages of production might appear to have higher productivity, even though productivities in comparable tasks are identical) and the mix of skilled vs. unskilled workers (obviously, a firm or country that chose to use unskilled workers would have a lower productivity per worker, but just as high total factor productivity.)

Data on GDP per worker (which avoid some of these issues) are equally plagued by multiple interpretations, particularly related to the fact that GDP is not a good measure of economic performance, e.g. because of problems associated with health care and "defense" spending. See, e.g. Stiglitz et al. (2010).

45 In 2012, US ranked \#3, Sweden \#8, and Norway \#1; in the perhaps more relevant (as a measure of well being) inequality adjusted HDI, US ranked \#15, Sweden \#3, and Norway \#1.

${ }^{46}$ There is much controversy over the explanations and implications of differences in the rate of patenting across countries and over time-and the relationship between these differences and differences in the pace of innovation (e.g. observed differences may be more related to differences over time and across countries in patent laws and their implementation than to the pace of innovation.) For a brief review of some aspects of this controversy, see Dosi and Stiglitz (2014). (For further discussion of these issues, see also; Levin et al., 1987; Cohen et al., 2000; Schankerman, 1991 and Tellis and Golder, 1996; these studies not only question the importance of patents, but even the significance of the first mover advantage. See also Aghion et al., 2013).

${ }^{47}$ And for good reason, related to an assessment of the costs and benefits of patents.
}

of innovativeness is a result of its system of cutthroat competition or reflected in higher standards of living for most citizens.

The US may have focused its innovative efforts in those sectors where patents are important and where rent-seeking is encouraged (as in the financial sector). If this is the case, then from the perspective of global innovation, it may be advantageous to have an ecology in which there are different institutional arrangements: there is no dominant one.

\section{Equilibrium gaps between leaders and followers}

In this section, we present a model in which there is an equilibrium gap between leaders and followers. Those at the frontier balance out the costs and benefits of pushing out the frontier faster; so too for those behind, who may have "catching up" policies aimed at closing the gap between them and the leaders; but they fail to catch up, simply because as they do so, the leader moves on. Policies designed to catch up are, however, different from those designed to move the frontier outward. We provide a theoretical characterization of these differences, and illustrate with some relevant policy examples.

\subsection{Equilibrium knowledge gaps across countries}

\subsubsection{Basic model}

We assume there are two types of goods-one industrial or manufacturing $(\mathrm{M})$ and the other agricultural/craft $(\mathrm{A})$, both produced using only labor as an input with constant returns to scale. We define

$$
\begin{gathered}
\mathrm{C}_{\mathrm{M}}\left(\mathrm{C}_{\mathrm{A}}\right) \equiv \text { amount of labor per unit of industrial (agricultural) } \\
\text { output in the economy. }
\end{gathered}
$$

The production possibilities curve is a straight line with a negative slope of $-c_{A} / c_{M}$. (See Fig. 1A.) All individuals are identical with utility functions among goods of the form (each period)

$\mathrm{U}=\alpha_{\mathrm{M}} \ln \mathrm{C}_{\mathrm{M}}+\left(1-\alpha_{\mathrm{M}}\right) \ln \mathrm{C}_{\mathrm{A}}$.

$C_{A}$ is the level of consumption of the A-goods, and $C_{M}$ is the level of consumption of the M goods. The labor supply is assumed fixed. ${ }^{48}$

If there were a single country, static utility maximization would occur at the tangency between the indifference curve and the production possibilities curve.

Assume now that there are two countries (or two groups of countries), the developed and the less developed, denoted respectively by superscripts D and L. Individuals in each have the same utility functions. The developing country has an absolute disadvantage in all production (i.e. $\mathrm{C}^{\mathrm{D}}{ }_{\mathrm{M}}<\mathrm{C}^{\mathrm{L}}{ }_{\mathrm{M}}$ and $\mathrm{C}^{\mathrm{D}}{ }_{\mathrm{A}}<\mathrm{C}^{\mathrm{L}}{ }_{\mathrm{A}}$ ), but a comparative advantage in agriculture.

$\mathrm{C}^{\mathrm{D}}{ }_{\mathrm{A}} / \mathrm{C}^{\mathrm{D}}{ }_{\mathrm{M}}>\mathrm{C}^{\mathrm{L}}{ }_{\mathrm{A}} / \mathrm{C}^{\mathrm{L}}{ }_{\mathrm{M}}$

To simplify the analysis, we assume the developing country is relatively small. This means that in free trade, the terms of trade are set by the developed country.

Because the developed country has a comparative advantage in industrial goods, under free trade, the developing country specializes in agricultural goods.

Fig. 1B shows the country's "consumption possibilities curve”, which because of trade is far better than its production possibilities curve.

\footnotetext{
48 This is not an innocuous assumption. One can establish a steady state equilibrium with endogenous labor supply only under a restrictive set of utility functions, of which the logarithmic utility function is one. If, as here, we assume a fixed labor supply, all that we require for steady-state analysis is constant elasticity utility functions. This parameterization simplifies the calculations. Qualitative results would be similar in these more genera models.
} 


\subsubsection{Dynamics}

We now introduce technological progress into this static equilibrium. We assume that learning-by-doing ${ }^{49}$ associated with industrial production within the country is the sole source of productivity increases, but that the learning by any firm spills over to all other firms within the country-both within its sector and in other sectors, i.e., ${ }^{50}$

$\mathrm{g} \equiv \mathrm{d}\left(\operatorname{lnc}_{\mathrm{M}}\right) / \mathrm{dt}=-\mathrm{d}\left(\operatorname{lnc}_{\mathrm{A}}\right) / \mathrm{dt}$.

Productivity growth does not affect the production costs of industrial goods relative to agricultural/craft goods, so that over time there is no change in comparative advantage.

There is considerable evidence of the presence of substantial spillovers. Not only are there technological spillovers, but improvements in human capital which arise in one sector inevitably confer benefits on others, e.g. as workers migrate to other sectors of the economy. Institutional innovations (like a well-developed financial sector which is essential for the functioning of a modern industrial sector) also confer benefits on other sectors. The assumption that the cross-sector spillovers are perfect is, of course, a polar case. We can loosen this assumption, but none of the qualitative results depend on it.

For all countries, the rate of technological progress increases with the output of the industrial sector or its input of labor or its relative size, measured say by the proportion of labor force allocated to the industrial sector, $\pi$, or the ratio of the outputs. For simplicity, we take the latter view: While in an industry with larger production, there can be more learning, what happens in one part of the industry has to diffuse to the rest of the sector. We assume that that these effects just offset each other.

We further assume that the follower country's growth also depends on the gap in knowledge between the developed and less developed country.

$\mathrm{g}^{\mathrm{D}}=\mathrm{f}^{\mathrm{D}}\left(\pi^{\mathrm{D}}, 1\right)$

$g^{\mathrm{L}}=\mathrm{f}^{\mathrm{L}}\left(\pi^{\mathrm{L}}, \kappa\right)$

where $\kappa=\mathrm{c}^{\mathrm{D}}{ }_{\mathrm{M}} / \mathrm{c}^{\mathrm{L}}{ }_{\mathrm{M}}$, the gap in productivity in the industrial sector, $\kappa<1$. We assume that (in the obvious notation) $\mathrm{f}^{\mathrm{L}}{ }_{2}<0$ for $\kappa<1$ (recalling that a larger value of $\kappa$ means a smaller gap); and $\mathrm{f}_{2}^{\mathrm{L}}=0$ for $\kappa \geq 1$, i.e. learning in the country which is more advanced is unaffected by the state of the less advanced country. ${ }^{51}$ For simplicity, we assume $\mathrm{f}^{\mathrm{D}}\left(\pi^{\mathrm{D}}, 1\right)=\mathrm{f}^{\mathrm{L}}\left(\pi^{\mathrm{L}}, 1\right),{ }^{52}$ for $\pi^{\mathrm{D}}=\pi^{\mathrm{L}}$ and where there is no loss of ambiguity, we drop the superscripts on $g$ and f. For later reference, we assume $\mathrm{f}_{12}<0$, i.e. the greater the knowledge gap, the greater the marginal return to learning (at any value of $\pi$ ).

\footnotetext{
49 There is a large literature on learning by doing, with empirical work even pre-dating Arrow's (1962b) development of the theory. For a more recent review of some of this literature, see Greenwald and Stiglitz (2014). An important aspect of technological progress is learning to learn. See Stiglitz (1987c).

${ }^{50}$ Again, this assumption greatly simplifies the analysis, but the results can be generalized. Note, however, that if there are imperfect spillovers, each firm will take into account the reduction in its future costs from increased production as a result of learning-by-doing. Firms that produce more will face lower costs. The competitive equilibrium will not be sustainable. With many commodities, there can exist a monopolistically competitive equilibrium. This model is very similar to that of Matsuyama (1992), except he assumes no spillovers. This changes the results in important ways. See Stiglitz (2014f).

${ }_{51} \mathrm{f}^{\mathrm{D}}$ does not depend at all on $\mathrm{\kappa}$. We write the equation in this way simply for convenience. Even countries that are, in general, behind may make innovations from which the leader benefits (America learned from Japan's just-in-time inventory control system). There are learning benefits from the laggard to the leader. Extending the model to incorporate this effect is straightforward.

${ }^{52}$ When there is no knowledge gap, they have the same learning functions. In fact, even when there is no knowledge gap about technology, there can still be a gap in learning capacities.
}

The crucial assumptions that distinguish this model from conventional growth theory are that productivity growth is endogenous and that knowledge does not flow freely across borders. In conventional growth theory, the rate of growth is exogenous, not affected by anything the firm (or society) does. ${ }^{53}$ While some forms of knowledge do move easily across borders, many others (tacit knowledge, knowledge related to the conduct of particular institutions) may be far less mobile than labor or capital.

With free trade, the global general equilibrium is easy to describe. For the large, developed country, with full learning spill-overs, each firm takes the state of technology next period as given - unaffected by what it does itself - and hence the competitive equilibrium in the absence of trade is the same as it was without learning, represented by the tangency of the indifference curves to the production possibilities locus. We denote the competitive equilibrium levels of output by $\left\{C_{M}{ }^{*}, C_{A}{ }^{*}\right\}$.

The small developing country takes prices as given, essentially set by the large developed country at its relative cost of production, and so the developing country specializes in agriculture.

Under free trade, because the developing country specializes in agricultural goods, with no knowledge spillovers from the developed to the less developed countries, the developing country stagnates.

\subsubsection{Long-run analysis with industrial policies}

Assume instead that the developing country directly controls production, allocating a fraction $\pi$ of its labor force to producing industrial goods, so its income (using agricultural goods at time 0 as our numeraire) is $\mathrm{Y}=$ $\pi \mathrm{k}+(1-\pi)$, where $\mathrm{k}=\mathrm{c}^{\mathrm{L}}{ }_{\mathrm{M}} / \mathrm{C}^{\mathrm{D}}{ }_{\mathrm{M}}<1$ represents the lower productivity associated with industrial production. ${ }^{54}$ Then, using Eq. (1)

$\mathrm{U}=\alpha_{\mathrm{M}} \ln (1-\lambda)+\left(1-\alpha_{\mathrm{M}}\right) \ln \lambda+\ln \mathrm{Y}=\mathrm{U} *$

where $\lambda$ is the proportion of income allocated to agricultural goods.

$\mathrm{U}$, short run utility, is maximized by maximizing $\mathrm{Y}$, and $\mathrm{Y}$ is maximized at $\pi=0$; that is, the country specializes in the production of agricultural goods, as noted above. It is also easy to show that $\lambda=1-\alpha_{\mathrm{M}}$.

We now put this into a dynamic setting, asking how taking into account learning benefits affects resource allocations. The present discount value of utility is

$\mathrm{W}=\sum \delta^{\mathrm{t}} \mathrm{U}^{\mathrm{t}}$

where $\delta$ is the utility discount factor. We focus on the steady state solution, where whatever policy is optimal at time $t$ is optimal at time $t+1 .^{55}$ This means that we can rewrite Eq. (5) as ${ }^{56}$

$\mathrm{W} \equiv[\mathrm{U}+\delta(\ln (1+\mathrm{g}) / 1-\delta)] /(1-\delta)$.

Optimality requires (for an interior solution) ${ }^{57}$

$\partial U * / \partial \ln \pi+\mathrm{f}_{\pi} \pi \delta /(1-\delta)(1+\mathrm{g})=0$

\footnotetext{
53 In standard "convergence" models, knowledge flows freely from one country to another, so that, effectively by assumption, $\kappa=1$. In this Ricardian version of the neoclassical model, convergence occurs instantaneously. If capital flows freely, even if savings rates differ, output per capita will be the same in different countries, but incomes will differ.

${ }^{54} \mathrm{k}$ is a measure of the difference in comparative advantage; $\kappa$ is a measure of the difference in absolute advantage in the industrial sector.

55 A full analysis would entail a more complicated dynamic programming formulation. The steady state analysis conveys the key issues at play.

${ }^{56} \mathrm{U}^{\mathrm{t}+1}=\mathrm{U}^{\mathrm{t}}+\ln (1+\mathrm{g})$, and, using standard techniques, $\mathrm{W}=\Sigma \mathrm{U}^{0}[(1+\mathrm{n}(\ln (1+\mathrm{g})))$ One parenthesis has been added to balance the delimiters. Please check that this was done correctly, and amend if necessary.] $\delta^{t}$, from which Eq. (6) follows directly.

If $U$ is not logarithmic but exhibits constant elasticity with respect to the scale of consumption, there is a parallel analysis.

57 If at $\pi=0, \partial U^{*} / \partial \ln \pi+f_{\pi} \pi /(1-\delta)(1+g)<0$, then there can be a corner solution at $\pi=0$, and if at $\pi=1, \partial \mathrm{U}^{*} / \partial \ln \pi+\mathrm{f}_{\pi} \pi /(1-\delta)(1+\mathrm{g})>0$, there can be a corner solution at $\pi=1$. In particular, this means that if $\mathrm{f}_{\pi}(0, \kappa) /(1-\delta)(1+\mathrm{f}(0, \kappa))<1-\mathrm{k}$, then $\pi=0$
} 

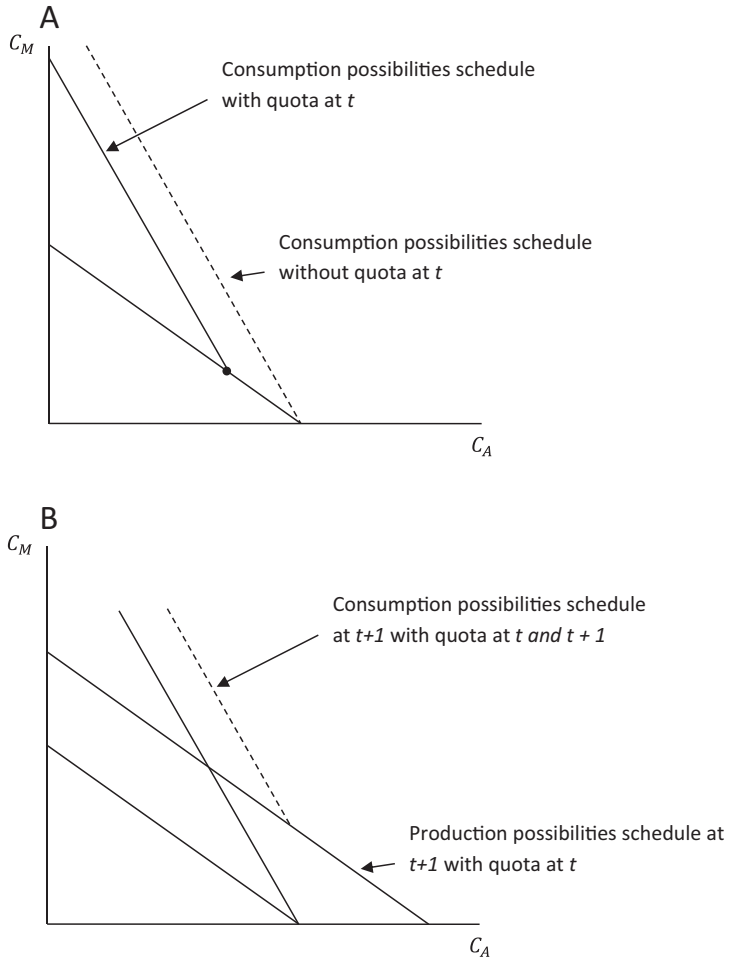

Fig. 2. A: Assume the country, rather than specializing in agriculture, produces some manufactured goods, and then trades agriculture goods to buy the rest of the manufactured goods it desires. Its new consumption possibilities curve is depicted in Fig. 2A, decidedly inferior to the "free trade" solution. B shows what happens in future periods. Because now there is learning, which benefits both sectors, the production possibilities curve has moved out. Even with the trade restriction, the consumption possibilities curve is better than in the free trade solution. There is a trade-off: a loss in well-being in the short run, for a gain in the long run.

Taking into account the learning (growth) benefits, the increase in future utility, so long as $\mathrm{f}_{\pi}>0$ (there is a marginal benefit to growth from expanding the industrial sector) and $\delta>0$ (the country cares about the future); optimality requires that $\partial \mathrm{U}^{*} / \partial \ln \pi<0$, i.e. $\pi>0$.

The country should produce some of the industrial good, even though it is not its comparative advantage (and under our assumptions, never will be). The dynamic benefits of learning exceed the static costs. Industrial policies pay off.

What is at issue is illustrated in Fig. 2A and B. Assume the country, rather than specializing in agriculture, produces some manufactured goods, and then trades agriculture goods to buy the rest of the manufactured goods it desires. Its new consumption possibilities curve is depicted in Fig. 2A, decidedly inferior to the "free trade" solution. But Fig. 2B shows what happens in future periods. Because now there is learning, which benefits both sectors, the production possibilities curve has moved out. Even with the trade restriction, the consumption possibilities curve is better than in the free trade solution. There is a trade-off: a loss in well-being in the short run, for a gain in the long run. Eq. (7) says that it always pays to impose some trade restriction.

The greater the learning benefit and the higher $\delta$ (the lower the discount factor), the higher $\pi$, the larger the industrial sector; that is, the higher the optimal static distortion. ${ }^{58}$

A similar analysis follows for the Leader. Denote by $\pi^{\mathrm{D}}{ }_{\mathrm{o}}$ the value of $\pi$ in the developed country in the free trade-no industrial policy equilibrium. So long as $f_{1}\left(\pi^{D}, 0\right)>0$, it pays for the developed as well as the less developed countries to undertake industrial policies.

\footnotetext{
58 This follows from the fact that that $\partial \mathrm{U}^{*} / \partial \pi=-(1-\mathrm{k}) / \mathrm{Y}<0$ and $\partial^{2} \mathrm{U}^{*} / \partial \pi^{2}=-(1-\mathrm{k})^{2} / \mathrm{Y}^{2}>0$. There is always a marginal cost to increasing $\pi$, but the larger is $\pi$, the smaller is $Y$, and therefore the larger is the marginal cost.
}

\subsubsection{Steady state gaps: the normal case}

In steady state, the less developed country stays a certain distance behind, i.e. there is a steady state value of $\kappa$, denoted $\kappa^{*}$, such that

$\mathrm{g}^{*} \equiv \mathrm{f}\left(\pi^{\mathrm{D} *}, 1\right)=\mathrm{f}\left(\pi^{\mathrm{L}}, \kappa^{*}\right)$

where, it will be recalled, we have assumed for simplicity that the developing country is very small relative to the developed, so that the developed country's equilibrium value of $\pi$ (essentially) depends on its own internal conditions. ${ }^{59}$ (That is $\pi^{\mathrm{D} *}$ is set simply by the demand for industrial goods domestically, and depends on whether it undertakes industrial policies).

Eq. (8) defines a positively sloped curve (is depicted as the upward sloping "steady state curve" (SS) in Fig. 3 ) between $\kappa$ and $\pi^{\mathrm{L}}$ : as $\kappa$ increases, the pace of learning slows (there is less to learn), and so for the developing country to maintain the same distance from the frontier, $\pi^{\mathrm{L}}$ must be increased.

The steady state solution is defined by the solution to Eq. (8) and the first order condition for the less developed country's welfare maximization, which we write in reduced form as

$W_{\pi}=0$.

$\kappa$ is the state variable describing the less developed economy - its "state of knowledge" relative to the developed country. For each value of $\kappa$ there is an optimal value of $\pi$ :

$\pi^{L}=P(\kappa)$

This is the profit maximizing (PM) curve. This is normally negatively sloped, so long as the marginal return to growth from increasing $\pi$ diminishes as $\kappa$ increases. ${ }^{60}$

There is thus a unique solution, as depicted in the figure: a steady state with a value of $\kappa=\kappa^{*}<1$ (implying the persistence of a knowledge gap of a given size) with a value of $\pi^{\mathrm{L}}$ that is less than $\pi^{\mathrm{D}}$. This is what we label as the normal situation, when it doesn't pay the developing country to close the knowledge gap, but it does pay it to deviate from static comparative advantage (and to do so persistently) so as not to fall too far behind-so that it can learn more effectively from the developed country advances in technology which are of benefit to all sectors of its economy. Even though the country would benefit from spillovers even if it didn't have an industrial sector, it would get fewer spillovers.

The infant never fully grows up, but to keep up with big brother, he has to continue to have industrial protection. There is a benefit to being the laggard: it is able to maintain the same rate of growth of the developed country by taking advantage of the knowledge that flows down from the developed country with a smaller fraction of its labor force allocated to the industrial sector. It can take some advantage of its comparative advantage in agriculture.

\footnotetext{
${ }^{59}$ It would be an easy matter to generalize this to the case where the lagging country is non-negligible in size, and continues to import some industrial goods. We would then need an additional equation to solve simultaneously for $\pi^{\mathrm{L} *}$ and $\pi^{\mathrm{D} *}$

${ }^{60}$ Because we postulate that the economy is in steady state (the knowledge gap is fixed), the analysis is greatly simplified. Along the first order condition $\mathrm{W}_{\pi}=0, \mathrm{~d} \pi / \mathrm{d} \kappa=-\mathrm{W}_{\pi \kappa} / \mathrm{W}_{\pi \pi}$.

The denominator is always negative, so that the sign of $d \pi / d \kappa$ is the same as that of $W_{\pi \kappa}$ and the sign of $W_{\pi \kappa}$ is the same as that of $\left(f_{\pi \kappa} / f_{\pi}\right)-\left(f_{\kappa} / 1+f\right)$. We expect that an increase in $\kappa$ reduces growth (when there is less catching up, there is less growth, at a given level of $\pi$ ), and that an increase in $\kappa$ also reduces the marginal benefit of increasing $\pi$. In effect, we assume that the marginal effect dominates. But if the knowledge gap is too large the knowledge that accumulates in the developed country is less and less relevant to developing countries.

The full optimization problem is somewhat more complicated, because if the knowledge gap is closed, next year's optimization problem is different from this year's. The full optimization problem can be solved using standard techniques. The result is still that the optimal labor allocation $\pi$ will depend on the state variable $\kappa$. The results described in the following paragraphs depend only the relationship between $\pi$ and $\kappa$ having the indicated properties.
} 


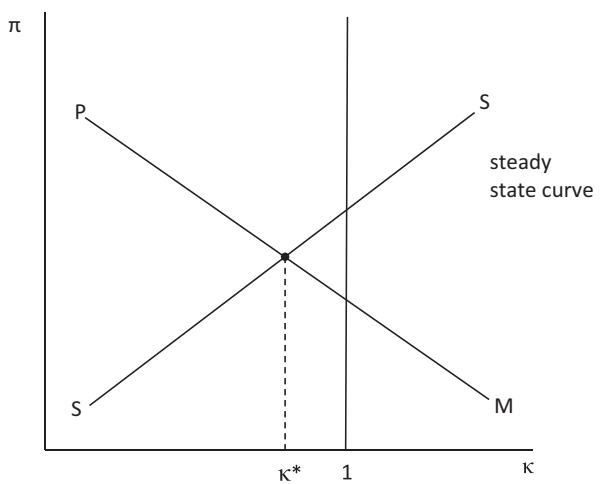

Fig. 3. The steady state equilibrium, showing the long run allocation of labor to manufacturing and the steady gap between the leader and the follower. Along the steady state locus, SS, as $\kappa$ increases, the pace of learning slows (there is less to learn) at any value of $\pi^{\mathrm{L}}$, and so for the developing country to maintain the same distance from the frontier, $\pi^{\mathrm{L}}$ must be increased. The steady-state equilibrium entails the catching-up firm remaining always behind. The PM locus shows the profit maximizing value of $\pi^{\mathrm{L}}$ for any value of the gap. As the gap increases, we assume not only does the level of learning at any $\pi^{\mathrm{L}}$ increase so does the marginal return to "learning by doing," so $\pi^{\mathrm{L}}$ increases.

Other possible configurations may emerge: the infant may catch up; it may be optimal to have no industrial policy, simply absorbing whatever knowledge trickles down to it; and there can be multiple equilibria-countries can be trapped in a low level equilibrium marked by a high knowledge gap, but with a positive enough boost, can move into a better steady state equilibrium, with higher levels of consumption and a much smaller gap with the leading countries. (See the Stiglitz (2014e) for the conditions associated with each of these possibilities.)

\subsubsection{Impact of industrial policies in advanced countries}

The steady state equilibrium depends on whether the advanced country pursues an industrial policy (i.e. takes into account that its growth rate $\mathrm{g}$ can be affected by its labor allocation). If it does (and our previous analysis showed that normally it would want to do so), $\mathrm{g}^{*}$ will be higher than it otherwise would have been, so $\pi^{\mathrm{L}}$ has to increase, at each $\kappa$, i.e. the SS curve, defined by (13), shifts up. This in turn means that (a) in steady state, the developing country will also have a higher growth rate; but (b) it will have to have a stronger industrial policy, i.e. a greater distortion in the static allocation of labor; and (c) the equilibrium gap between the developed and the less developed country will be larger. (See Fig. 4).

\subsection{Optimal policies for leaders and followers}

So far, we have assumed that there is a single policy (industrial policy) that can affect growth. But countries have at their disposal a large range of policies that might affect growth. We generalize Eq. (8) describing the rate of growth of the economy to ${ }^{61}$

$\mathrm{g}=\mathrm{f}(\pi, \kappa, \mathrm{s})$,

where $s$ is any growth enhancing measure, ${ }^{62}$

$\partial \mathrm{g} / \partial \varsigma>0$

We assume further that there is a short run social cost of these measures beyond a certain level, $\mathrm{s}^{*}$ that maximizes short run utility. Thus, we write the short run (momentary) utility as

$\mathrm{U} *(\pi, \varsigma)$

with $\partial \mathrm{U}^{*} / \partial \varsigma<0$ for $\varsigma>\varsigma^{*}$.

\footnotetext{
61 The growth functions of the two countries could themselves differ. Here, we argue that even if the growth functions are identical, policies will still differ.

62 It is of, course, possible that some measures increase growth over some range, and decrease growth over others. We ignore this possibility in this paper.
}

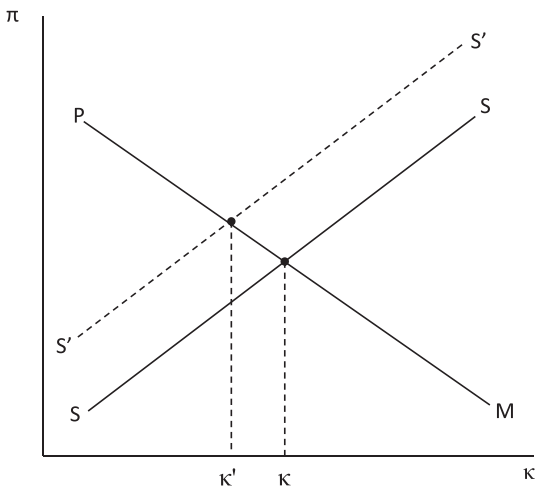

Fig 4. This figure shows the impact of industrial policies in advanced countries. If the advanced country pursues an industrial policy, g* will be higher than it otherwise would have been, so $\pi^{\mathrm{L}}$ has to increase, at each $\kappa$, i.e. the SS curve, defined by Eq. (8), shifts up.

The leader (the large, developed country) maximizes long-term social welfare with respect to $\mathrm{s}$, taking into account the short run costs and the long run benefits. It follows that the leader sets $s>\varsigma^{*}$.

The follower goes through a similar exercise, but for the follower, $\kappa<1$ (in contrast to the leader, where $\kappa=1$, by definition), and $\pi^{\mathrm{L}}<\pi^{\mathrm{D}}$. The marginal growth benefits of increasing $\varsigma$ will be affected by the growth cross elasticities between $\varsigma, \kappa$, and $\pi$. Policies which are growth enhancing for the leader (for whom $\kappa=1$ ) may not be growth enhancing for the followers, or may be much less so.

It follows that unless the growth equation $\left(8^{\prime}\right)$ is separable between $\varsigma$, on the one hand, and $\kappa$ and $\pi$ on the other, ${ }^{63}$ the optimal value of $\varsigma$ for the leader will differ from that of the follower(s), even if they have the same preferences: economic policies designed for advancing the technological frontier are different from those that optimize "catching up," borrowing technologies from others.

Assume, for instance, $\varsigma$ stands for "basic research" and that the level of basic research required to maintain a knowledge gap-given that knowledge is filtering down in any case-is less than that required for moving the frontier forward at the rate $\mathrm{g}^{*}$. Then the follower (the developing country) should do less research than the developed country.

Sometimes, however, there has been an underappreciation of what is required to close the knowledge gap-or to prevent the knowledge gap from growing. At one time, the World Bank encouraged developing countries to devote essentially all of their educational resources to primary education, with very little allocated to university education. While well-intentioned, the effect of such policies was that the countries that followed them fell increasingly technologically behind. The 1998 World Development Report, Knowledge for Development (World Bank, 1998) helped bring about a reversal of that policy. If $s$ is interpreted as "university education," while $\varsigma^{\mathrm{L}}<\varsigma^{\mathrm{D}}$, it argued that still, $\varsigma^{\mathrm{L}}>0$.

There are active debates about the role of different policies for both leaders and followers, e.g. concerning the role and design of pecuniary incentive structures, including intellectual property rights, the importance of openness and collaboration, and the impact of inequality and competition. Theoretical results appear to be heavily dependent on particular assumptions, and empirical results remain contingent and unsettled.

While in many respects, leaders would do well to follow the Nordic model-consistent with the analysis of Section 3 suggesting that the Nordic countries were in fact innovation leaders - and, with appropriate modification, so should followers, there are some dimensions in which markedly different policies might be appropriate. An intellectual property regime which is designed to move the frontier out as fast as possible may be markedly different from an intellectual property

\footnotetext{
63 That is, since the follower will always face a different value of $\kappa$ and, in general, have a different value of $\pi$, in general, without separability, the optimal value of $s$ will differ
} 
regime that is designed to close the gap between the technology at the frontier and technologies prevailing within a laggard country. ${ }^{64}$

If frontier research is more risky, policies that enable individuals within society to cope with those risks will be more important in frontier countries, unless risk aversion diminishes sufficiently with increases in income. If the winner-take-all processes that characterize the frontier countries lead to greater inequality, given imperfections of capital markets discussed in Section 2, it may be especially important for a frontier country to have a strong public education system that guarantees access to education for all, if the human resources of that country are to be efficiently deployed. These observations suggest that a Nordic model may be particularly relevant for the leader.

In short, "optimal" policies for innovation may be similar in some respect to, but differ markedly in others, from those which are conducive to enhancing imitation (catch up); but contrary to the assertion of Acemoglu et al. variants of the Nordic model may actually enhance well-being in both.

\subsection{Extensions}

The central model that we explored is one in which there are full spillovers across sectors, so that if the less developed country initially has a comparative advantage in agriculture/crafts, it always does. That means that if the country wants to have an industrial sector, it must permanently provide some protection. It is perhaps incorrect to say that the infant never grows up: productivity in manufacturing may increase enormously, and the gap between productivity in that sector in the developed and developing country may narrow markedly. But because of the assumption of full spillovers, comparative advantage never changes. This has one very important implication:

Even if it were true that infant industries sometimes never fully grow up, the support provided by the government to the industrial sector pays off: the economy is on a long-term faster growth trajectory than it otherwise would have had.

But a country like Korea represents the more typical story, where as it learns, productivity in the industrial sector increases faster than in agriculture, so much so that eventually the country's comparative advantage changes. That means that eventually government intervention to maintain a (relatively) large industrial sector - larger than would be the case under unfettered market forces - is no longer required. But even after the country achieves some success in improving manufacturing capacities, it may still want to intervene, to produce more manufacturing goods than it otherwise would have produced, or more broadly, to encourage the expansion of those sectors with higher learning and innovation potential, and higher learning and innovation spillovers.

Of course, the uncoordinated equilibrium that emerges is not globally efficient. Because the leader does not take into account the benefits of the innovation that "trickle down" from it to the followers, it will engage in too little innovation, adopting policies that are less supportive than would be desirable from a global perspective. It may also undertake policies that excessively inhibit the flow of knowledge from itself to the followers. There is obviously a role for global collective action, for addressing the market/government failures that arise when each country pursues the policies directed solely at enhancing the well-being of its own citizens.

\footnotetext{
64 Thus, the WIPO (World Intellectual Property Organization) General Assembly adopted a proposal from Brazil and Argentina on October 4, 2004 calling for a developmentally oriented intellectual property regime, as opposed the regime incorporated into the TRIPS agreement, which was widely seen as impeding access to knowledge, and thus development.
}

\subsection{Concluding comments}

This paper is an exercise in comparative economic systems, asking what kind of an economic system most enhances welfare, focusing especially on innovation and the production and dissemination of knowledge. Rather than beginning from the presumption that there is a single economic system that is best for all countries, it recognizes that different countries may be in markedly different situations: there are leaders and followers. What is optimal for a leader, trying to move the frontier ahead (and perhaps maximizing its innovation rents) may be different from that which is optimal for the follower, trying to take advantage of knowledge produced by others, trying to catch up, or at least not fall behind.

We have begun our analysis by a brief articulation of the multiple market failures that characterize innovation and the production and dissemination of knowledge. There is no presumption that unfettered markets will be optimal, in either the level or direction of investments in research. There is a presumption that there are government interventions that will enhance welfare.

Central to our analysis is the idea that the production and dissemination of knowledge is different from the production and dissemination of conventional goods; and the presumptions and understandings of what leads to good economic performance relevant for the latter may not be relevant for the former. Standard economic models assume that knowledge disseminates easily (and typically, costlessly) within and between countries. There is, however, overwhelming evidence that there are large and persistent differences in knowledge within and between countries. That this is so has profound implications. It means, for instance, that reforms that improve the efficiency with which information/knowledge gets transmitted within and between countries can have a far more profound effect on standards of living than those that improve the allocative efficiency of the economy, especially when such reforms simultaneously impede the flow of knowledge. It implies that simple injunctions for firms (countries) to become leaders, to move to the technological frontier, are of little relevance.

We have formulated a simple model in which countries can close the gap with the technological leader-but there is a cost to doing so, and the cost is sufficiently high that a country may choose to remain a laggard. ${ }^{65}$ There exists an international equilibrium, in which there are leaders and followers. ${ }^{66}$

Market failures affect both the supplies and prices of inputs into innovation as well as the risk-adjusted private and social returns. The Nordic model can be thought of as addressing in a fairly comprehensive way these market failures. Policies affecting education, social protection, especially of children, unions, public investments in technology and infrastructure, active labor market policies, industrial policies-all of these not only affect societal wellbeing directly, but also the pace of innovation. Though there are some features of the American form of capitalism that are conducive to innovation, there are others that are not; and that while there may be questions about precisely how strong its economic performance has been, say in comparison to the Nordic countries, it is clear that what success it has attained can only partially be attributed to its markets and its form of cutthroat capitalism: some is a result of a historical accident, some can be attributed to its not-for-profit universities, some to strong government support.

We have argued that there is a strong role for government to play in both the leader and the follower countries, in designing policies that lead to more innovation or ensuring that the knowledge gap doesn't

\footnotetext{
65 The fact that there are a few countries, such as Korea, which have gone a long way in closing the knowledge/technological gap, is not necessarily inconsistent with the hypotheses put forward in this paper. Such countries may have underestimated the cost of closing the gap, may have unusually low time discount factors, or may face distinct circumstances in which the costs of closing the gap are unusually small.

${ }^{66}$ There are other models generating non-convergence. In the appendix to the NBER version of this paper, we discuss the important differences between our model and that of Krugman (1981) and Matsuyama (1992).
} 
increase, and in ensuring that innovations disseminate well within the economy and that most citizens benefit. As we noted, without the appropriate frameworks, innovations can lead most citizens to be worse off, even if the winners could have compensated the losers.

In democracies, whether governments adopt policies that facilitate innovation will depend on the consequences of innovation for most citizens. The Nordic model, by ensuring that more of its citizens benefit from innovation and growth, has created a virtuous circle: a political regime that supports policies that facilitate innovation and ensures that the benefits of the resulting growth are widely shared. ${ }^{67}$

\section{References}

Acemoglu, D., 2010. When does labor scarcity encourage innovation? J. Polit. Econ. 118 (6), 1037-1078 (December).

Acemoglu, D., Robinson, J., Verdier, T., 2012. Can't we all be more like Scandinavians? MIT Working Paper (March).

Aghion, P., Bloom, N., Blundell, R., Griffith, R., Howitt, P., 2005. Competition and innovation: an inverted-U relationship. Q. J. Econ. 120 (2), 701-728.

Aghion, P., Howitt, R., Prant, S., 2013. Patent rights, product market reforms, and innovation. Working Paper (February).

Arrow, K.J., 1962a. Economic welfare and the allocation of resources for invention. In: Nelson, R. (Ed.), The Rate and Direction of Inventive Activity: Economic and Social FactorsNational Bureau of Economic Research (NBER). Princeton University Press, Princeton, NJ, pp. 609-626.

Arrow, K.J., 1962b. The economic implications of learning by doing. Rev. Econ. Stud. 29, 155-173.

Baily, M.N., Hulten, C., Campbell, D., Bresnahan, T., Caves, R.E., 1992. Productivity dynamics in manufacturing plants. Brook. Pap. Econ. Act. Microeconomics 1992, 187-267.

Barro, R.J., Sala-I-Martin, X., 1991. Convergence across states and regions. Papers 629. Yale Economic Growth Center.

Barth, E., Finseraas, B., Moene, K.O., 2012. Political Reinforcement: How Rising Inequality Curbs Manifested Welfare Generosity, mimeo, University of Oslo.

Barth, E., Moene, K.O., Willumsen, F., 2013. The Scandinavian model: an interpretation. Working Paper (May 29).

Benabou, R., 1997. Inequality and growth. NBER Macroeconomics Annual 1996 vol. 11. MIT Press, pp. 11-92.

Biais, B., Woolley, P., 2011. High frequency trading. IDEI Working Paper (available at http://idei.fr/doc/conf/pwri/biais_pwri_0311.pdf).

Blundell, R., Graber, M., Mogstad, M., 2014. Labor income dynamics and the insurance from taxes, transfers, and the family. IFS Working Paper W14/01.

Boldrin, M., Levine, D.K., 2013. The case against patents. J. Econ. Perspect. 27 (1), 3-22.

Budish, E., Roin, B.N., Williams, H., September 2013. Do fixed patent terms distort innovation? Evidence from cancer clinical trials, NBER Working Paper No. 19430.

Chang, Ha-Joon, 2001. Intellectual property rights and economic development: historical lessons and emerging issues. J. Hum. Dev, Capabilities 2 (2), 287-309.

Chang, Ha-Joon, 2002. Kicking Away the Ladder: Development Strategy in Historical Perspective. Anthem Press, London.

Cimoli, M., Dosi, G., Maskus, K., Okediji, R., Reichman, J., Stiglitz, J., 2014. The role of intellectual property rights in developing countries: some controversial conclusions. In: Cimoli, M., Dosi, G., Maskus, K., Okediji, R., Reichman, J., Stiglitz, J. (Eds.), Intellectua Property Rights and Development. Oxford University Press, Oxford/New York.

Clarkson, G., DeKorte, D., 2006. The problem of patent thickets in convergent technologies. Ann. N. Y. Acad. Sci. 1093 (1), 180-200.

Cohen, W., Nelson, R.R., Walsh, J., 2000. Protecting their intellectual assets: appropriability conditions and why US manufacturing firms patent or not. Discussion Paper 7552 . NBER.

Dasgupta, P., David, P.A., 1994. Toward a new economics of science. Policy Res. 23, 487-521.

Dasgupta, P., Stiglitz, J.E., 1980a. Uncertainty, market structure and the speed of R\&D. Bell J. Econ. 11 (1, Spring), 1-28.

Dasgupta, P., Stiglitz, J.E., 1980b. Industrial structure and the nature of innovative activity. Econ. J. 90 (358), 266-293.

Dasgupta, P., Stiglitz, J.E., 1988. Potential competition, actual competition and economic welfare. Eur. Econ. Rev. 32 (May), 569-577.

David, P.A., 2004a. From keeping nature's secrets to the institutionalization of open science. In: Ghosh, R.A. (Ed.), Collaborative Ownership and the Digital Economy (CODE). MIT Press, Cambridge Mass, pp. 85-108.

David, P.A., 2004b. Understanding the emergence of 'Open Science' institutions: functionalist economics in historical context. Ind. Corp. Chang. 13, 571-589.

Delli Gatti, D., Gallegati, M., Greenwald, B.C., Russo, A., Stiglitz, J.E., 2012a. Mobility constraints, productivity trends, and extended crises. J. Econ. Behav. Organ. 83 (3) 375-393.

Delli Gatti, D., Gallegati, M., Greenwald, B.C., Russo, A., Stiglitz, J.E., 2012b. Sectoral imbalances and long run crises. In: Allen, F., Aoki, M., Fitoussi, J.-P., Kiyotaki, N., Gordon, R., Stiglitz, J.E. (Eds.), The Global Macro Economy and FinanceIEA Conference vol. No. 150-III. Palgrave, Houndmills, UK and New York, pp. 61-97.

${ }^{67}$ By the same token, some of the policies of the US that impede innovation are a result of political processes that reflect the political influence of special interests, like the financia sector.
DeLong, J.B., 1988. Productivity growth, convergence, and welfare: comment. Am. Econ. Rev. 78 (5), 1138-1154

Domar, E.D., Musgrave, R.A., 1944. Proportional income taxation and risk-taking. Q. J. Econ. 58, 388-422.

Dosi, G., Stiglitz, J.E., 2014. The role of intellectual property rights in the development process, with some lessons from developed countries: an introduction. In: Cimoli, M., Dosi, G., Maskus, K., Okediji, R., Reichman, J., Stiglitz, J. (Eds.), Intellectual Property Rights and Development. Oxford University Press, Oxford/New York.

Dosi, G., Nelson, R., Freeman, C., Soete, L., Silverberg, G. (Eds.), 1988. Technical Change and Economic Theory. Pinter, London.

Dosi, Giovanni, Marengo, L., Pasquali, C., 2006. How Much Should Society Fuel the Greed of Innovators? On the Relations Between Appropriability, Opportunities and Rates of Innovation. Research Policy 35 (8), 1110-1121.

Dowrick, S., Nguyen, D.T., 1989. OECD comparative economic growth 1950-85: catch-up and convergence. Am. Econ. Rev. 79 (5), 1010-1030.

Durlauf, S.N., Quah, D.T., 1999. The new empirics of economic growth, In: Taylor, J.B., Woodford, M. (Eds.), Handbook of Macroeconomics, edition 1 Handbook of Macroeconomics vol. 1. Elsevier, pp. 235-308 (chapter 4).

Esping-Andersen, G., 1990. The Three Worlds of Welfare Capitalism. Polity Press, Cambridge.

European Commission, 2008. Pharmaceutical sector inquiry: preliminary report. DG Competition Staff Working Paper: 9.

Field, Alexander J., 2011. A Great Leap Forward: 1930s Depression and U.S. Economic Growth. Yale University Press, New Haven.

Fochesato, M., Bowles, S., 2015. 'Nordic exceptionalism?' Social democratic egalitarianism in world-historic perspective. J. Public Econ. 127, 30-44

Freeman, C., 1995. The national system of innovation in historical perspective. Camb. J. Econ. 19, 5-24

Fudenberg, R.G., Tirole, J., Stiglitz, J.E., 1983. Preemption, leapfrogging and competition in patent races. Eur. Econ. Rev. 22 (June), 3-32.

Gertner, J., 2012. The Idea Factory: Bell Labs and the Great Age of American Innovation. Penguin, Londo.

Gilbert, R., 2006. Looking for Mr. Schumpeter: where are we in the competitioninnovation debate? In: Jaffe, A., Lerner, J., Stern, S. (Eds.), Innovation Policy and the Economy vol. 6. MIT Press, Cambridge.

Goettler, R.L., Gordon, B.R., 2011. Does AMD spur Intel to innovate more? J. Polit. Econ. 119 (6), 1141-1200.

Goettler, R.L., Gordon, B.R., 2014. Competition and product innovation in dynamic oligopoly. Quant. Mark. Econ. 12, 1-42.

Goldstone, L., 2014. Birdmen: The Wright Brothers, Glenn Curtiss and the Battle to Control the Skies. Random House Press.

Greenwald, B., Stiglitz, J.E., 2006. Helping infant economies grow: foundations of trade policies for developing countries. Am. Econ. Rev. Pap. Proc. 96 (2), 141-146.

Greenwald, B., Stiglitz, J.E., 2014. Creating a Learning Society: A New Approach to Development and Social Progress. Columbia University Press, New York.

Habakkuk, H.J., 1962. American and British Technology in the Nineteenth Century. Cambridge University Press, London.

Hall, P.A., Soskice, D., 2001. Varieties of Capitalism: The Institutional Foundation of Comparative Advantage. Oxford University Press, Oxford.

Hart, Oliver, 1983. The market mechanism as an incentive scheme. Bell J. Econ. 14 (2), 366-382.

Heller, M., 1998. The tragedy of the anticommons: property in transition from Marx to markets. Harv. Law Rev. 111, 698-701.

Heller, M., Eisenberg, R., 1998. Can patents deter innovation? The anti-commons in biomedical research. Science 280, 698-701.

Henry, C., Stiglitz, J.E., 2010. Intellecutal property, dissemination of innovation, and sustainable development. Glob. Policy 1 (1), 237-251.

Hicks, J.R., 1932. The Theory of Wages1963 2nd ed. Macmillan, London.

Hoff, K., Stiglitz, J.E., 2004. After the big bang? Obstacles to the emergence of the rule of law in post-communist societies. Am. Econ. Rev. 94 (3), 753-763.

Huang, K.G., Murray, F.E., 2008. Does patent strategy shape the long-run supply of public knowledge? Evidence from human genetics. Acad. Manag. J. 52 (6), 1193-1221.

Im, F.G., Rosenblatt, D., 2013. Middle-income traps: a conceptual and empirical survey. Policy Research working paper, no. WPS 6594. World Bank, Washington, DC

Janeway, W., 2012. Doing Capitalism in the Innovation Economy. Cambridge University Press, Cambridge, UK

Kaplan, S., Lerner, J., 2010. It ain't broke: the past, present, and future of venture capital. J. Appl. Corp. Financ. 22 (2), 36-47.

Krugman, P., 1981. Trade, accumulation and uneven development. J. Dev. Econ. 8, 149-161.

Levin, R., Klevorick, A., Nelson, R.R., Winter, S., 1987. Appropriating the returns from industrial R\&D. Brook. Pap. Econ. Act. 1987 (3), 783-831.

Lundvall, B.-Å. (Ed.), 1992. National Innovation Systems: Towards a Theory of Innovation and Interactive Learning. Pinter, London.

Mankiw, G., Romer, D., Weil, D., 1992. A contribution to the empirics of economic growth. The Quarterly Journal of Economics 107(2). MIT Press, pp. 407-437.

Matsuyama, K., 1992. Agricultural productivity, comparative advantage, and economic growth. J. Econ. Theory 58, 317-334.

Mazzucato, M., 2013. The Entrepreneurial State. Anthem Press.

Merton, R.K., 1973. The Sociology of Science: Theoretical and Empirical Investigations. University of Chicago Press, Chicago.

Moene, K., 2013. "Scandinavian Equality: A Prime Example of Protection Without Protectionism. In: Kaldor, Mary, Stiglitz, Joseph E. (Eds.), The Quest for Security: Protection without Protectionism and the Challenge of Global Governance. Columbia Unversity Press, New York, pp. 48-74. 
Moser, P., 2013. Patents and innovation: evidence from economic history. J. Econ. Perspect. 27 (1), 23-44.

Nalebuff, B., Stiglitz, J.E., 1983. Prizes and incentives: toward a general theory of compensation and competition. Bell J. 14 (1), 21-43 (Spring, Reprinted).

The Selected Works of Joseph E. Stiglitz, Volume II: Information and Economic Analysis: Applications to Capital, Labor, and Product Markets. Oxford University Press, Oxford, pp. 407-431.

National Science Foundation (NSF), 2014. Science and Engineering Indicators 2012available online at http://www.nsf.gov/statistics/seind14/index.cfm/chapter-4/c4h.htm (accessed May 14, 2014).

National innovation systems. In: Nelson, R. (Ed.), A Comparative Analysis. Oxford University Press, New York/Oxford.

Nordhaus, W.D., 1969. Invention, Growth and Welfare: A Theoretical Treatment of Technological Change, Cambridge, Mass. 1969, (Ch. 5).

Organisation for Economic Co-operation and Development, 2011. Strong Performers and Successful Reformers in Education: Lessons from PISA for the United States, OECDavailable online at http://www.oecd.org/pisa/46623978.pdf (accessed November 12, 2013).

Ostry, J.D., Berg, A., Tsangarides, C.G., 2014. Redistribution, inequality and growth. IMF Discussion Paper (February).

Patel, P., Pavitt, K., 1994. The nature and economic importance of national innovation systems. STI Review 14. OECD, Paris.

Piketty, T., 2014. Capital in the Twenty-First Century. Belknap (Harvard University) Press, Cambridge.

Piketty, T., Saez, Emmanuel, Stantcheva, Stefanie, 2011. Taxing the 1\%: why the top tax rate could be over $80 \%$. Vox, (December 8 ).

Salop, S.C., Scheffman, D.T., 1983. Raising rivals' costs. Am. Econ. Rev. 267-271.

Salter, W.E.G., 1966. Productivity and Technical Change. Cambridge Univ. Press, Cambridge.

Schankerman, M., 1991. How valuable is patent protection? Estimates by technology field using patent renewal data. NBER Working Paper No. 3780.

Scherer, F., 1967. Market structure and the employment of scientists and engineers. Am. Econ. Rev. 57 (3), 524-531.

Schumpter, J., 1943. Capitalism, Socialism and Democracy. Harper, New York.

Shapiro, C., 2001. Navigating the patent thicket: cross licenses, patent pools, and standard-setting. In: Jaffe, A.B., et al. (Eds.), Innovation Policy and the Economy I. MIT Press, Cambridge, pp. 119-150.

Shapiro, C., 2010. Injunctions, hold-up, and patent royalties. Am. Law Econ. Rev. 12 (2), $280-313$.

Solow, R., 1956. A contribution to the theory of economic growth. Q. J. Econ. 70 (1), 65-94.

Stiglitz, J.E., 1969. The effects of income, wealth and capital gains taxation on risk-taking. Q. J. Econ. 83 (2), 263-283.

Stiglitz, J.E., 1987a. Technological change, sunk costs, and competition. Brook. Pap. Econ. Act. 3, 883-947.
Stiglitz, J.E., 1987b. On the microeconomics of technical progress. In: Katz, Jorge M. (Ed.), Technology Generation in Latin American Manufacturing Industries. Macmillan Press Ltd., New York, pp. 56-77 (Originally presented to IDB-CEPAL Meetings, Buenos Aires, November 1978).

Stiglitz, J.E., 1987c. Learning to learn, localized learning and technological progress. In: Dasgupta, P., Stoneman (Eds.), Economic Policy and Technological Performance. Cambridge University Press, pp. 125-153.

Stiglitz, J.E., 2006a. Making Globalization Work. W W Norton, New York

Stiglitz, J.E., 2006b. Samuelson and the factor bias of technological change. In: Szenberg M., et al. (Eds.), Samuelsonian Economics and the Twenty-First Century. Oxford University Press, New York, pp. 235-251.

Stiglitz, J.E., 2012a. The Price of Inequality: How Today's Divided Society Endangers our Future. WW Norton, New York

Stiglitz, J.E., 2012b. Macroeconomic fluctuations, inequality, and human development. J. Hum. Dev. Capabilities 13 (1), 31-58 (Reprinted).

Nayyar, Deepak (Ed.), 2013b. Macroeconomics and Human Development. Taylor and Francis.

Stiglitz, J.E., 2014a. Intellectual property rights, the pool of knowledge, and innovation. Working Paper. Columbia University.

Stiglitz, J.E., 2014b. Creative destruction. Working Paper. Columbia University.

Stiglitz, J.E., 2014c. Competition and innovation. Working Paper. Columbia University.

Stiglitz, J.E., 2014d. Unemployment and innovation. Working Paper. Columbia University.

Stiglitz, J.E., 2014e. Tapping the brakes: are less active markets safer and better for the economy? Paper Prepared for Presentation at Atlanta Federal Reserve Conference April 15, 2014

Stiglitz, J.E., 2014f. Leaders and followers: perspectives on the Nordic model and the economics of innovation. NBER Working Paper.

Stiglitz, J.E., Sen, A., Fitoussi, J.-P., 2010. Mismeasuring Our Lives: Why GDP Doesn't Add Up. The New Press, New York.

Sutch, R., 2010. The unexpected long-run impact of the minimum wage: an educational cascade. In: Rhode, P.W., Rosenbloom, J.L., Weiman, D. (Eds.), Economic Evolution and Revolution in Historical Time. Stanford University Press, Palo Alto, Calif, pp. 387-418.

Tellis, G.J., Golder, P.N., 1996. First to market, first to fail? Real causes of enduring market leadership. MIT Sloan Manag. Rev. 37 (2), 65-75.

Vives, X., 2008. Innovation and competitive pressure. J. Ind. Econ. 56 (3), 419-469.

Williams, H., July 2010. Intellectual Property Rights and Innovation: Evidence from the Human Genome. NBER Working Paper No. 16213.

Williams, H.L., 2013. Intellectual Property Rights and Innovation: Evidence from the Human Genome. Journal of Political Economy 121 (1), 1-27.

World Bank, 1998. World Development Report 1998-1999: Knowledge for Development. The World Bank, Washington, D.C.

Wright, G., 1986. Old South, New South: Revolutions in the Southern Economy Since the Civil War. Basic Books, New York 